Historic, Archive Document

Do not assume content reflects current scientific knowledge, policies, or practices. 

ONARGA NURSERY COMPANY

Not Incorporated
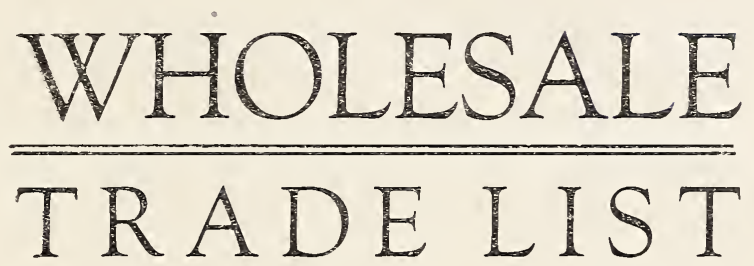

of

DFDENDABIF

NURSERT STDEK

Gor the Grade Only

500 ACRES

\section{FALL 1928}

$$
\text { I865- I928 }
$$

A. J. CULTRA $\}$ Managers ONARGA, ILLINOIS H. B. CUTRRA $\}$ Managers

YOU WILL BE PLEASED WITH OUR SERVICE 


\section{TERMS OF SALE}

CASH PLAN: This plan earns $3 \%$ discount and free boxing. Remittances must be received on or before March 1st to earn this discount. On bulky stock, boxing sometimes amounts to 6 or $8 \%$, so this plan earns a total of from 6 to $10 \%$ discount. Under this plan we book the order, and reserve the stock until March 1st for shipment.

PARTIAL PAYMENT PLAN: Whereby one-third amount or order is remitted in advance, and the balance goes forward Freight or Express C. O. D. payable at destination.

CREDIT: We extend the usual terms of credit to regular customers and to parties known to us; otherwise we require cash in advance or satisfactory reference with sufficient time before shipment to make necessary investigation. We will not accept orders until we believe that the buyer is good for the account. Fall shipments due December 1st, Spring shipments due June 1st.

PRICES: On amounts above 5 and under 10 apply ten rate. On amounts under 10 apply ten rate. On amounts 25 and over apply 100 rate. On amounts 250 and over apply 1000 rate.

GUARANTY: While we exercise the utmost diligence and care to have our stock true to name and hold ourselves in readiness on proper proof, to replace all trees, etc., that prove otherwise, or refund the amount paid, it is mutually understood and agreed between the purchaser and ourselves that we shall not in any case be liable for any sum greater than the amount originally received for said trees, etc., that prove untrue.

All orders are accepted by us upon the mutual agreement between the purchaser and ourselves that we shall not be responsible for other damages.

This catalogue cancels all previous price lists. Prices net no discount.

A certificate of inspection will accompany each order.

CLAIMS: No claims for rejections or deficiencies wiil be entertained unless made within five days after arrival of goods. In no case will we assume responsibility after consignment to purchaser. When losses occur by delays or other causes of whatever nature while goods are in transit, make claim $\mathbf{A T}$

ONCE on the forwarding companies.

CAUTION: We accept all orders upon condition that they shall be void should injury befall stock froni frost, fire, hail storms or other causes over which we have no control.

PACKING: Packing will be done in the best possible manner, and charged for at the cost of material used. Boxes alid bales delivered free of charge to all railway stations. After goods are delivered to forwarder in good condition our responsibility ceases.

REFERENCE: Onarga State Bank, Onarga, I11. Mercantile Agencies.

\section{NOTICE!}

All goods sold by us are sold f. o. b. point of shipment, and while in transit are at purchaser's risk. We feel it is our duty to emphasize the fact that we do not insure the safe delivery of goods and that the title of any goods sold by us and consigned to the purchaser or consignee designated by purchaser passes to the purchaser upon delivery by us to the carrier at point of shipment.

And we desire to make it clear to the trade that the railroad or Express Company's receipt relieves us of all responsibility, and any claim for damages should be made immediately to the agent at the point of delivery.

\section{SEND US YOUR LIST OF WANTS}

We can often quote lower than our published rates on quantity lots. 


\section{FRUIT DEPARTMENT}

APPLES, Large sizes for city trade

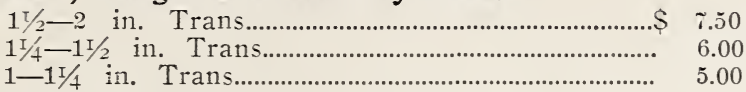

\section{APPLES}

2 year well branched

Those marked with * are sc higher

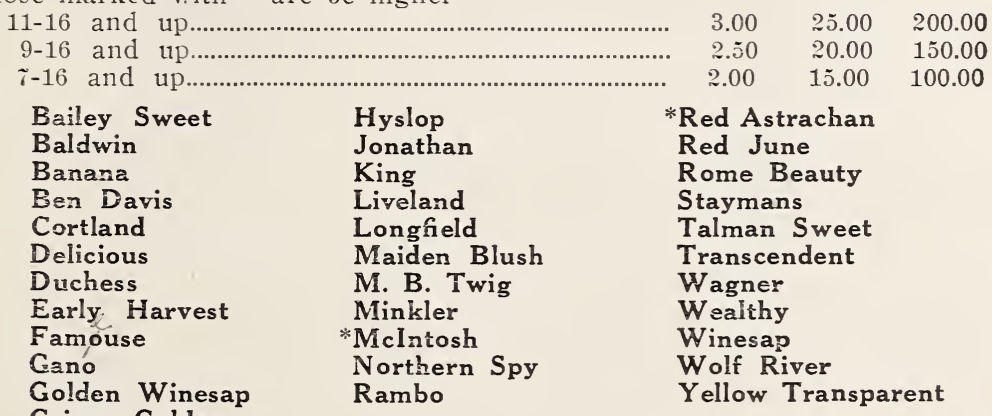

\section{DWARF APPLES}

5-8 and up.

Baldwin
Delicious
Duchess
Gravenstein

King

Miclntosh

Northern Spy

Red Astrachan R. I. Greening Wagner

\section{APRICOT}

9-16 and up.

i-16 and up

$$
\begin{aligned}
& \text { Early Golden } \\
& \text { Moorepark }
\end{aligned}
$$

\section{CHERRIES}

\section{Sour Cherries, 1 or 2 year}

11-16 and up

9-16 and up.

$\tau-16$ and up.

\section{Dyehouse}

Early Richmond

\section{MONTMORENCY}

11-16 and up.

9-16 and up.

$i-16$ and up

Sweet Cherries, 1 year

11-16 and up

$9-16$ and up

$\tau-16$ and up

5-16 and up

Black Tart

Bing

Gov. Wood
Royal

Superb
$3.25 \quad 27.00$

$3.00 \quad 21.00$

$\begin{array}{lll}3.50 & 30.00 & 250.00 \\ 3.00 & 25.00 & 200.00 \\ 2.50 & 20.00 & 150.00\end{array}$

Wragg

English Morello

Ostheim 


\section{FRUIT DEPARTMENT (Continued)}

\section{PEACHES}

10

$100 \quad 1000$

First Class, general assortment

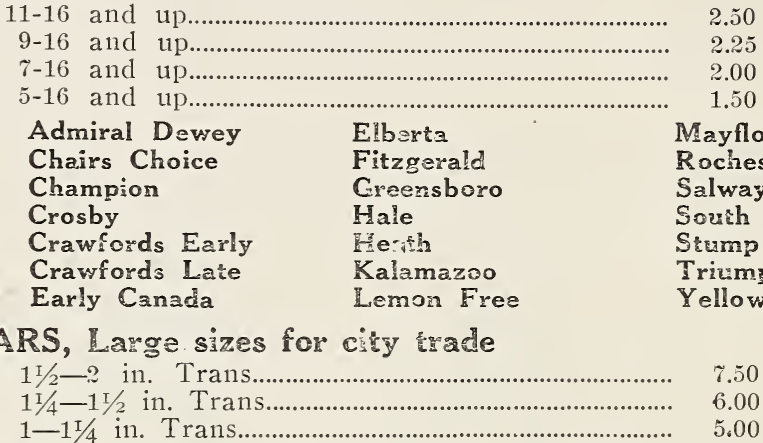

\section{PEARS}

\section{Standard}

11-16 and up...

9-16 and up...

$7-16$ and up....

Bartlett

Bosc

Clapps

Duchess

Dwarf

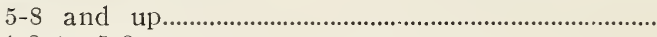

$1-2$ to $5-8$.

Douglas

Flemish

Keiffer

3-8 to $1-2$

Bartlett

Clapps

Seckel
3.50

$3.00-25.00$

$2.50 \quad 20.00$

$\begin{array}{rr}21.00 & 160.00 \\ 18.00 & 150.00 \\ 15.00 & 120.00 \\ 12.00 & 90.00\end{array}$

Seckel

Sheldon

Vt. Beauty

$\begin{array}{ll}3.50 & 30.00 \\ 3.00 & 25.00 \\ 2.50 & 20.00\end{array}$

\section{PLUMI}

\section{European Varieties}

11-16 and up

9-16 and up

7-16 and up

5-16 and up....

Abundance

Beauty Naples

Blue Damson

Bradshaw

Burbank

Fallenburg

Hansen Varieties

11-16 and up

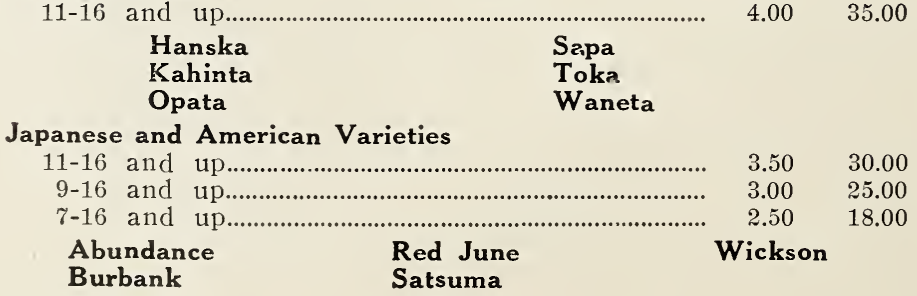




\section{FRUIT DEPARTMENT (Continusd)}

QUINCE

9-16 and up

:-16 and up

MULBERRY

$\begin{array}{ll}\text { Champion } & \text { Rea's Mammoth } \\ \text { Meech's Prolific } & \text { Orenge }\end{array}$

Russian

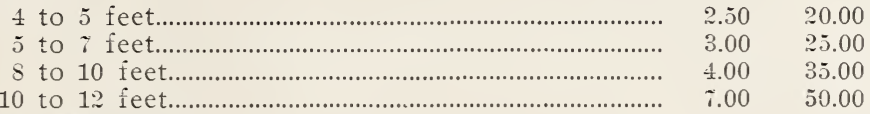

PERSIMMONS

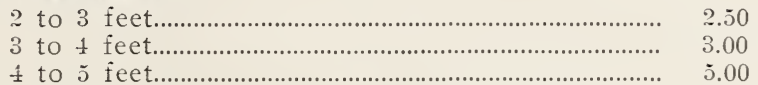

SMALL FRUITS

\section{CURRANTS AND GOOSEBERRIES}

\section{CURRANTS}

3 yr. No. 1

2 yr. No. 1

$1.75 \quad 10.00$

1 yr. No. 1

$1.50 \quad 6.00$

1 yr. No.

London Market

1.00

4.00

$.75 \quad 3.00$

Prince Albert

Red Dutch

White Grape

Perfection

Victoria

Wilder Red

2 yr. No. 1

$1.50 \quad 10.00$

\section{GOOSEBERRIES}

3 year

$2.00 \quad 15.00$

2 year

1.50

10.00

GRAPE VINES

2 yr. No. 1

1 yr. No. 1

1 yr. No. 2

\section{Agawam (Red) \\ Niagara (IThite) \\ Catawba (Red) \\ Salem (Red) \\ Moore's Diamond (White) \\ Worden (Blue) \\ Moore's Early (Blue)}

Brighton (Red)

2 yr. No. 1

1 vr. No. 1

Campbell's Early (Black)

1 yr. No. 1.

Concord (Blue)

3 yr. No. 1

$1.50 \quad 10.00$

$.75 \quad 6.00$

6.00
3.50

40.00

1 yr. No. 1

1 yr. No. 2 


\section{RASPBERRIES AND BLACKBERRIES}

\section{RASPBERRIES}

Cuthbert, (Red)

10

Columbian, (Purple)

2.00

15.00

Cumberland, (Black)

3.00

25.00

Cumberland, (Black) Trans.

Gregg and Kansas, (Black)

King, (Red) Trans

King and Loudon, (Red)

Latham (Red) Guaranteed free from Mosaic

Rathman, (Red)

St. Regis, (Everbearing)

$2.00 \quad 15.00$

$3.00 \quad 25.00$

$2.00 \quad 15.00$

$2.00 \quad 17.50$

$2.00 \quad 15.00$

$4.00 \quad 35.00$

$2.00 \quad 15.00$

$2.00 \quad 15.00$

\section{BLACKBERRIES}

Blower

Early Harvest, root cuttings

( $\$ 15.00 \mathrm{M}$ in 5000 lots or more)

Eldérado (\$20.00 M in 5M lots or more)

Snýder

$\begin{array}{lll}.50 & 3.50 & 30.00 \\ .50 & 3.50 & 20.00\end{array}$

$\begin{array}{lll}.50 & 3.00 \quad 25.00\end{array}$

$\begin{array}{lll}.50 & 3.00 \quad 20.00\end{array}$

\section{STRAWBERRIES}

Leading sorts, inciuding

Dr. Burrill, Early Mitchell, Stephen's Late, Warfield, Dunlap, Prolific, Tennessee

Aroma, Gibson, Haverland, Parker's Beauty, Chas. I., Glen Mary, Kellogg's Prize.

Mastádon, New, only everbearing variety of commercial value ( $\$ 15.00 \mathrm{M}$ in $5 \mathrm{M}$ lots or more)

Progressive and Superb

\section{RHUBARB AND GARDEN PLANTS}

Rhubarb, Linneaus and Victoria

\begin{tabular}{|c|c|}
\hline year ...... & 1.50 \\
\hline year & 1.00 \\
\hline 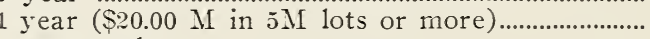 & .75 \\
\hline 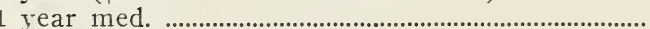 & .50 \\
\hline
\end{tabular}

\section{ASPARAGUS}

1 yr. No. 1

2 yr. No. 1

\section{ORNAMENTAL SHADE TREES}
AILANTHUS (Tree of Heaven)
Glandulosa
3 to 4 feet
4 to 6 feet 


\section{ORNAMENTAL SHADE TREES (Continued)}

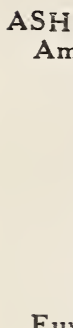

$\mathrm{SH}$ (Fraxinus)

4 to 6 feet.

6 to 8 feet

8 to 10 feet.

$11 / 4$ to $11 / 2$ inch stem

$1 \frac{1}{2}$ to $13 / 4$ inch stem

2 inch stem

2 to $2 \frac{1}{2}$ inch stem

$2 \mathrm{I} / 2$ to 3 inch stem

3 inch stem

European Flountain

5 to 6 feet.

6 to 8 feet

8 to 10 feet

$1 \frac{1}{4}$ to $1 \frac{1}{2}$ inch stem

$1 \frac{1}{2}$ to $13 / 4$ inch stem.

BOX ELDER (Acer Negundo)

8 to 10 feet.

$11 / 4$ to $1 \frac{1}{2}$ inch stem.

\section{BUCKEYE (Aesculus)}

Yeliow

$1 \frac{T}{2}$ inch stem

Each

2 inch stem

\section{CATALPA}

6 to 8 feet.

8 to 10 feet.

$11 / 4$ to $11 / 2$ inch sten

ELM (Ulmus)

American White

6 to 8 feet.

$\mathrm{S}$ to 10 feet.

$11 / 4$ to $1 \frac{1}{2}$ inch stem

$11 / 2$ to $13 / 4$ inch stem.

$13 / 4$ to 2 inch stem.

2 to $21 / 2$ inch stem.
$21 / 2$ to 3 inch stem.

Moline

$S$ to 10 feet.

\section{HACKBERRY (Celtis)}

8 to 10 feet.

$1 \frac{1}{2}$ to 2 inch stem.

2 to $21 / 2$ inch stem.

$2 \mathrm{I} / 2$ to 3 inch stem.

3 inch stem.

HORSECHESTNUT (Aesculus)

Flore Pleno (White Flowering)

4 to 5 feet.

6 to 8 feet.

LINDEN (Tilia)

American

6 to 8 feet.

8 to 10 feet

10 to 12 feet.

$1 \mathrm{t} / 2$ to $13 / 4$ inch stem.

$13 / 4$ to 2 inch stem.
10

5.50

1000

$10.00 \quad 55.00$

$12.50 \quad 100.00$

15.50

1 1..50

30.00

32.50

35.00

40.00

5.00

6.50

11.50

17.50

22.50

10.00

12.50

75.00

100.00

2.00

3.50

$\frac{1}{x} .50$

10.00

$6.50 \quad 60.00$

$8.00 \quad 75.00$

7.50

60.00

$12.50 \quad 100.00$

$17.50 \quad 150.00$

$25.00 \quad 200.00$

$30.00 \quad 250.00$

$35.00 \quad 300.00$

$45.00 \quad \$ 00.00$

15.00

15.00

17.50

20.00

30.00

35.00

$\$ 0.00$

20.00

30.00

12.50

17.50

20.00

22.50

27.50 
ORAAMENTAL SHADE TREES (Continued)

LOCUST (Robinia)

10

100

1000

Black (Pseudoacacia)

$t$ to 5 feet

3.C0 25.00

6 to 8 feet.

5.50

50.00

s to 10 feet

10.00

$\% 5.00$

$1 \frac{1}{4}$ to $1 \frac{1}{2}$ inch stem

12.50

100.00

3 inch stem.

20.00

30.00

Honey (Gleditsia)

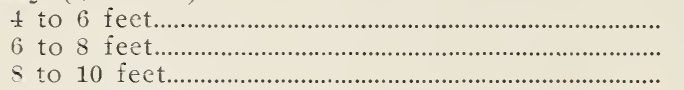

$5.50 \quad 50.00$

$7.50 \quad \approx 0.00$

$12.50 \quad 100.00$

10 to 12 feet

$15.00 \quad 125.00$

$1 / 2$ to 2 inch stem.

$20.00 \quad 150.00$

2 inch stem.

25.00

\section{MAGNOLIA}

Accuminata and Tripetla

3 to 4 feet.....

\pm to 5 feet.

7.50

\section{MAPLE (Acer)}

\section{Bloodleaf Japanese Maple (Palmatum Atropurpureum)} 12 to 18 inch $B$ \& $B$

is to $2 \pm$ inch B \& B

Norway (Platanoides)

6 to 8 feet branched.

8 to 10 feet branched.

10 to 12 feet branched

25.00

\section{Schwedlerii}

6 to 7 feet whips.

$15.50 \quad 150.00$

$i$ to 8 feet whips

$16.50 \quad 160.00$

6 to 8 feet br.

8 to 10 feet br.

$25.00 \quad 200.00$

$1 \mathrm{I} / 4$ to $1 / 2$ inch br

$35.00 \quad 300.00$

Soft (Dasycarpum)

$1 \frac{1}{4}$ to $1 \frac{1}{2}$ inch stem

40.00

$11 / 2$ to $13 / 4$ inch stem

$13 / 4$ to 2 inch stem

$15.00 \quad 100.00$

$20.00 \quad 150.00$

$25.00 \quad 200.00$

2 to $21 / 2$ inch stem

$30.00 \quad 250.00$

$21 / 2$ to 3 inch stem

$35.00 \quad 300.00$

Sugar (Saccharum)

6 to 8 feet.

12.50

8 to 10 feet.

17.50

10 to 12 feet

25.00

$1 \frac{1}{2}$ to 2 inch stem

30.00

Wier (Dasycarpum IVieri) Cutleaf

5 to 6 feet

6 to 8 feet.

8 to 10 feet

$1 \frac{1}{4}$ to $1 \frac{1}{2}$ inch stem.

$11 / 2$ to $13 / 4$ inch stem

20.00

OAK (Quercus)

Pin (Palustris)

10 to 12 feet.

$1 \frac{1}{2}$ to $13 / 4$ inch stem

40.00

$13 / 4$ to 2 inch stem

45.00 


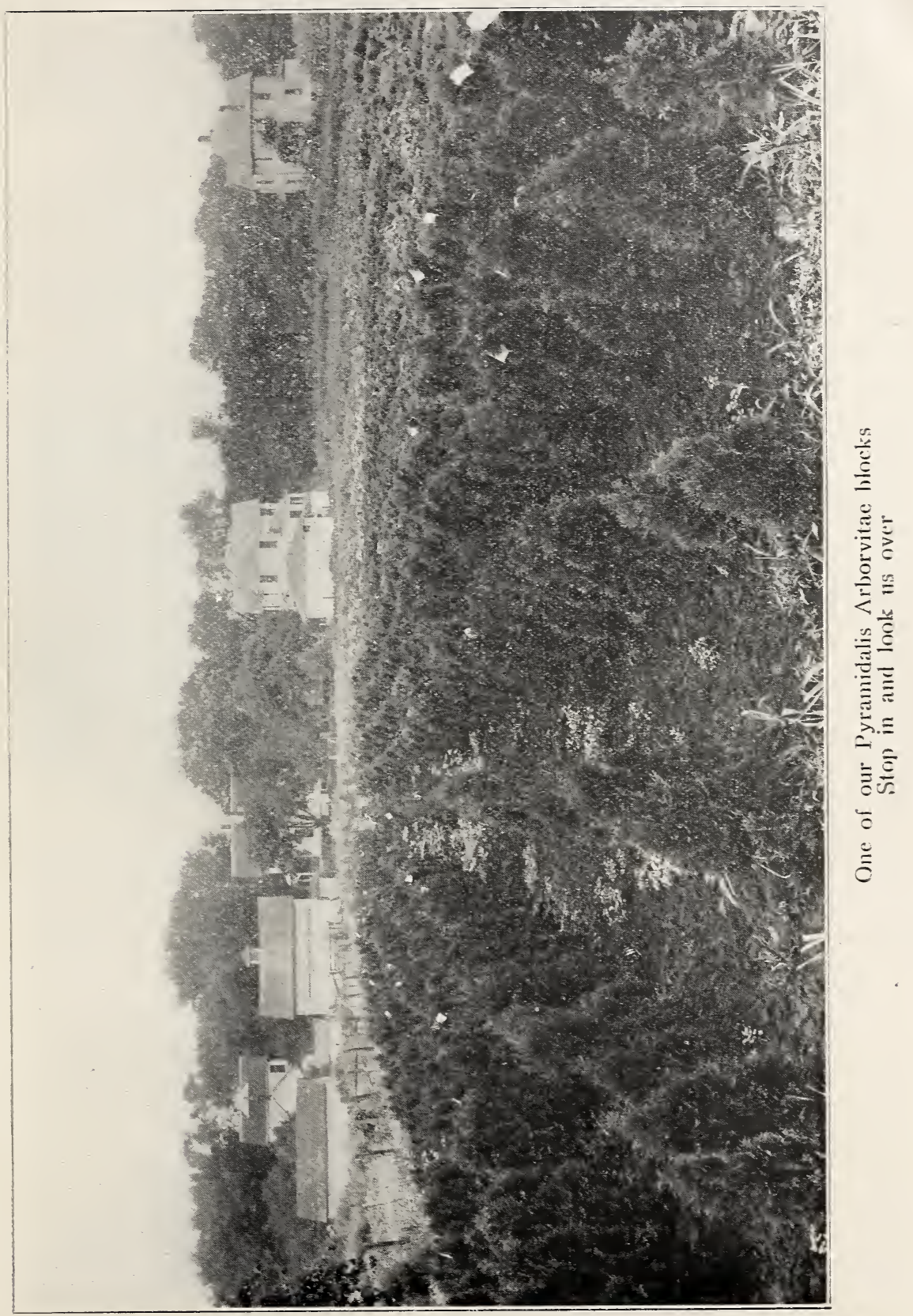




\section{ORNAMENTAL SHADE TREES (Continued)}

POPLAR (Populus)

10

100

1000

\section{Bolleana}

8 to 10 feet

12.50

100.00

Carolina and Norway (Monilifera)

6 to 8 feet

$2.00 \quad 18.00$

8 to 10 feet..............

3.00

25.00

10 to 12 feet

$3.50 \quad 30.00$

$11 / 4$ to $13 / 4$ inch stem.

$5.00 \quad 40.00$

$13 / 4$ inch stem.

$6.50 \quad 50.00$

2 inch stem................................................................ 8.50

$2 \mathrm{t} / 2$ inch stem........................................................... 10.00

3 inch stem.

15.00

Lombardy (Nigra Fastigiata) and Volga

5 to 6 feet.

15.00

125.00

6 to 8 feet.

2.50

20.00

8 to 10 feet

3.50

30.00

10 to 12 feet...

6.50

50.00

$8.00 \quad 75.00$

$1 \mathrm{I} / 2$ to $13 / 4$ inch stem.

$13 / 4$ to 2 inch stem

2 to $2 \frac{1}{2}$ inch stem.

15.00

100.00

3 inch stem.

17.50

150.00

250.00

\section{Simond's Pyramidal}

5 to 6 feet.

2.00

15.00

125.00

6 to 8 feet.

2.50

20.00

175.00

8 to 10 feet

3.50

30.00

250.00

10 to 12 feet.

6.50

50.00

400.00

$\begin{array}{rrr}8.00 & 75.00 & 500.00\end{array}$

$13 / 4$ to 2 inch stem.

15.00

100.00

750.00

2 to $2 \frac{1}{2}$ inch stem.

17.50

3 inch stem

150.00

250.00

Silver (Alba Nivea)

5 to 6 feet.

20.00

6 to 8 feet

2.50

30.00

8 to 10 feet

3.50

40.00

10 to 12 feet.

5.00

60.00

$1 \mathrm{t} / 2$ to 2 inch stem.

10.00

2 inch stem.

12.50

\section{SASSAFRAS}

4 to 6 feet

6 to 8 feet.

Sweet Gum (Liquid Amber)

3 to 4 feet.

5.00

SYCAMORE (Platanus)

American

4 to 6 feet

6 to 8 feet.

8 to 10 feet

$1 \frac{1}{4}$ to $1 \frac{1}{2}$ inch stem

12.50

2 to $2 \mathrm{I} / 2$ inch stem.

European (Oriental Planetree)

6 to 8 feet. 


\section{ORNAMENTAL SHADE TREES (Continued)}

\begin{tabular}{|c|c|c|}
\hline $\begin{array}{l}\text { THORN (Crataegus) } \\
\text { Assorted }\end{array}$ & 10 & 100 \\
\hline 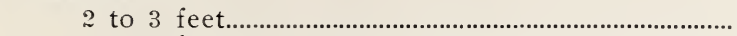 & 4.00 & 35.00 \\
\hline 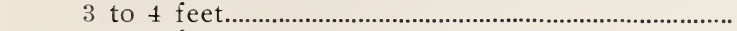 & 5.00 & 45.00 \\
\hline 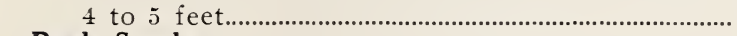 & 6.50 & 60.00 \\
\hline Pauls Scarlet & & \\
\hline 3 to 4 feet.... & 10.00 & 75.00 \\
\hline 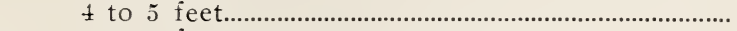 & 12.50 & 100.00 \\
\hline 5 to 6 feet.... & 15.00 & 125.00 \\
\hline TULIP TREE (Liriodendron) & & \\
\hline \pm to 5 feet..... & 4.00 & 50.00 \\
\hline 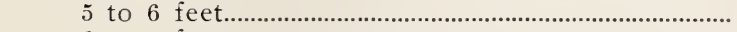 & 5.00 & $\approx 5.00$ \\
\hline 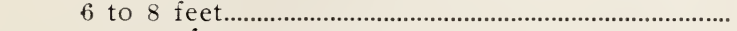 & 12.50 & 100.00 \\
\hline 8 to 10 feet.. & 15.00 & 125.00 \\
\hline 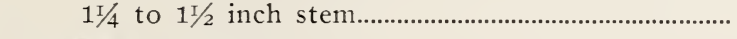 & $1 \tau .50$ & 150.00 \\
\hline $\begin{array}{l}\text { WALNUT (Juglans) } \\
\text { Black (Nigra) }\end{array}$ & & \\
\hline 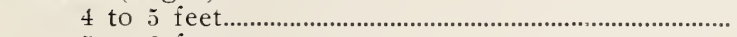 & 5.00 & 40.00 \\
\hline 5 to 6 feet....... & 6.00 & 55.00 \\
\hline 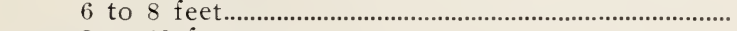 & 8.00 & 75.00 \\
\hline 8 to 10 feet... & 12.50 & 100.00 \\
\hline White (Cinerea) Butternut & & \\
\hline 4 to 5 feet........ & 5.00 & $\$ 0.00$ \\
\hline (1) & 6.00 & 55.00 \\
\hline 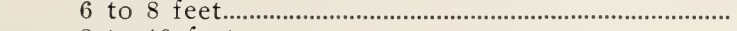 & 8.00 & 75.00 \\
\hline 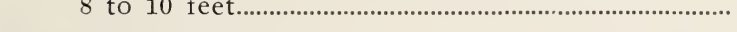 & 12.50 & 100.00 \\
\hline $\begin{array}{l}\text { WILLOW } \\
\text { Pussy (Cap }\end{array}$ & & \\
\hline 2 to & 1.50 & 10.00 \\
\hline$\ldots$ & 1.75 & 15.00 \\
\hline 4 to & 2.50 & 20.00 \\
\hline 6 to & 3.50 & 30.00 \\
\hline
\end{tabular}

WEEPING TREES

ASH, (Fraxinus)

\section{Weeping Mountain}

5 to 6 feet

BIRCH (Betula)

Cut Leaf Wpg.

4 to 5 feet

$\tilde{5}$ to 6 feet.

8 to 10 feet

\section{CATALPA}

\section{Chinese (Bungeii)}

1 year head 4 to 5 feet

1 year head 5 to 6 feet

2 year head $t$ to 5 feet

2 year head 5 to 6 feet

3 year head 5 to 6 feet

\section{CHERRY}

Japanese Weeping

1 year

\section{ELM}

\section{Camperdown Weeping}

No. 1 heads. 


\section{WEEPING TREES (Continued)}

MULBERRY (Morus)

Teas Weeping

1 year head

10

100

1000

2 year head.

$20.00 \quad 175.00$

$22.50 \quad 200.00$

WILLOW (Salix)

Thurlow and Wisconsin Wpg.

6 to 8 feet.

$4.50 \quad 40.00$

8 to 10 feet

$6.50 \quad 60.00$

10 to 12 feet.

$9.00 \quad 80.00$

$1 \mathrm{~T} / 4$ to $1 \mathrm{~T} / 2$ inch stem................................................... 12.50

$11 / 2$ to 2 inch stem......................................................... 15.00

\section{SPECIMEN EVERGREENS}

ABIES (Fir)

Douglassi (Douglas Fir)

2 Times Trans. 18 to 24 in B \& B

Each

\section{BIOTA}

Aurea. Nana (Berkman's Golden)

12 to 15 inch $\mathrm{B} \& \mathrm{~B}$

15 to 18 inch $\mathrm{B}$ \& $\mathrm{B}$

18 to 24 inch $B$ \& $\mathrm{B}$

24 to 30 inch $\mathrm{B} \& \mathrm{~B}$

\section{JUNIPERUS}

Chinensis Pftzeriana (Pfitzer Juniper)

12 to 18 inch $\mathrm{B}$ \& $\mathrm{B}$

18 to 24 inch $B$ \& B

24 to 30 inch $B$ \& $B$

3.25

30 to 36 inch $B$ \& $B$

Communis Depressi

10 to 12 inch $B$ \& $B$

30.00

$4.50 \quad 40.00$

12 to 18 inch $\mathrm{B} \& \mathrm{~B}$

$1.50 \quad 12.50$

100.00

$1.75 \quad 15.00$

125.00

Communis Hibernica (Irish Juniper)

18 to 24 inch $\mathrm{B}$ \& $\mathrm{B}$

2 to 3 feet $B$ \& B

3 to 4 feet $B$ \& $B$

$3.00 \quad 2 \% .50$

$t$ to 5 feet B \& B

$4.00 \quad 35.00$

English

2 to 3 feet $B$ \& B

$\begin{array}{ll}2.25 & 20.00 \\ 2.75 & 25.00\end{array}$

Excelsa Stricta (Spiny Greek Juniper)

12 to 18 inch heavy $\mathrm{B} \& \mathrm{~B}$

$2.00 \quad 17.50$

18 to 24 inch heavy $\mathrm{B} \& \mathrm{~B}$.

$3.00 \quad 25.00$

Sabina (Savin)

12 to 18 inch B \& B

$1.75 \quad 15.00$

125.00

18 to $2 \pm$ inch $\mathrm{B} \& \mathrm{~B}$

2.25

20.00

2 to $2 \frac{1}{2}$ feet B \& B

$2.75 \quad 25.00$

Sabina Prostrata (Prostrate Juniper)

18 to 24 inch $\mathrm{B} \&$ \&

$2.20 \quad 17.50$

24 to 30 inch B \& B

$2.50 \quad 22.50$

Virginiana (Red Cedar)

18 to 24 inch B \& B

$1.50 \quad 12.00$

2 to 3 feet heavy $B$ \& $B$

$1.75 \quad 15.00$

3 to 4 feet heavy B \& B

$3.00 \quad 25.00$

Virginiana Glauca (Silver Red Cedar)

18 to 24 inch B \& B.

2 to 3 feet $B \& B$ 


\section{SPECIMEN EVERGREENS (Continued)}

\section{PICEA}

Canadensis (White Spruce)

12. to 18 inch B \& B.

15 to 24 inch B \& B

Canaxlensis Albertiana (Black Hill Spruce)

$\because$ times trans. $1:$ to 18 inch B \& B

$\because$ to 3 feet heary B \& B

Engelmanni (Engelmann Spruce)

12. to 15 inch $\mathrm{B}$ \& $\mathrm{B}$

1s to $2 \pm$ inch $B$ \& $B$

2 to 3 feet $B$ \& B

Excelsa (Norway Spruce)

12 to 15 inch $\mathrm{B} \& \mathrm{~B}$

is to 24 inch $B$ \& $B$

$\approx$ to 3 feet $B$ \& B

3 to 4 feet $B$ \& B

4 to 5 feet B \& B

Pungens (Colorado Green Spruce)

15 to 24 inch $B$ \& $B$.

2 to $21 / 2$ feet $\mathrm{B} \& \mathrm{~B}$

Pungens Glauca (Colorado Bluc Spruce)

2 to 3 feet $B$ \& B.

3 to 4 feet $B$ \& $B$.

Pungens Kosreriana (Koster's Plue Spruce)

2 to 3 feet $B$ \& B.

3 to $t$ feet $B$ \& $B$

\section{PINUS}

Mugho Compacía (Dwari Mountain Pine)

$2 \pm$ to 30 inch B \& B

Sylvestris (Scotch Pine)

15 to $2 \pm$ irch $B$ \& $B$.

\section{THUJA}

Occidentalis (American Arbor Titae)

1 to $1^{1 / 2}$ feet $B \&$ B...

$1 \mathrm{~T} / 2$ to 2 feet heary $B$ \& $B$.

2 to 3 feet heary $B$ \& B

3 to 4 feet heary B \& B.

Occidentalis Lutea (Ccorge Pcabody Arbor Vitae)

is to 24 inch B \& B

$2 \pm$ to 30 inch $B$ \& $B$

30 to 36 inch $\mathrm{B} \& \mathrm{~B}$

Occidentalis Pyramidalis (Fyramidal Arbor Titae)

12 to 15 inch B \& B.

15 to $2 \pm$ inch B \& B.

2 to 3 feet heary $B$ \& $B$

3 to 4 feet heary $B$ \& $B$

5 feet heary B \& B.

6 feet heary B \& B

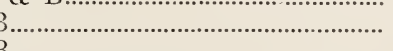

dii (Woodivard's Globe Arbor

Occidentalis Woodward
12 to 15 inch $B$ 足 $B$

\section{Each}

10

100

$1.25 \quad 10.00$

$1.50 \quad 12.50$

$1.50 \quad 12.50$

$3.00 \quad 2 \% .50$

$1.75 \quad 15.00$

$2.25 \quad 20.00$

$3.00 \quad 25.00$

. $55 \quad 6.00$

$1.00 \quad 9.00$

$1.50 \quad 12.50$

$3.00 \quad 2 \% .50$

$3.50 \quad 32.50$

$2.75 \quad 25.00$

$3.25 \quad 30.00$

S. 00

12.50

15.00

15.00

\subsection{5}

4.00

2000

35.00

$1.25 \quad 10.00$

50.00

$i 5.00$

100.00

150.00

s0.00 10 to 12 inch B \& B 12 to 15 inch $B$ \& $B$

75.00

2.25

4.25

6.00

40.00

55.00

i.50 $\quad$ 0.00

\subsection{0}

175.00

325.00

Vitae)

$1.25 \quad 10.00$

$2.00 \quad 15.00$

$2.25 \quad 20.00$

75.00

100.00

$2.50 \quad 22.50 \quad 150.00$ 


\section{SPECIMEN EVERGREENS (Continued)}

THUJA (Continued)

Orientalis (Oriental Arbor Vitae)

2 to 3 feet $B$ \& B

3 to 4 feet B \& B

Orientalis Compacta

12 to 18 inch $B$ \& $B$

18 to 24 inch $B$ \& $B$

2 to 3 feet B \& B.

Tom Thumb (Dwarf)

10 to 12 inch $\mathrm{B} \& \mathrm{~B}$

12 to 18 inch $\mathrm{B} \& \mathrm{~B}$

\section{RETINOSPORA}

\section{Plumosa}

15 to 18 inch $\mathrm{B} \& \mathrm{~B}$

$1 \mathrm{~L} / 2$ to 2 feet $\mathrm{B} \& \mathrm{~B}$

\section{Plumosa Aurea}

15 to 18 inch $\mathrm{B} \& \mathrm{~B}$

$1 \frac{1}{2}$ to 2 feet $B \& B$

TAXUS (Yew)

Cuspidata (Japanese Yew)

18 to 24 inch $\mathrm{B} \& \mathrm{~B}$

TSUGA (Hemlock)

\section{Canadensis}

12 to 15 inch $B$ \& $B$

15 to 18 inch $\mathrm{B} \& \mathrm{~B}$

18 to 24 inch B \& B
Each

10

100

$2.00 \quad 15.00$

$2.75 \quad 25.00$

$1.25 \quad 10.00$

$1.75 \quad 15.00$

$2.00 \quad 17.50$

$1.25 \quad 10.00$

$1.50 \quad 12.50$

$1.50 \quad 12.50$

100.00

$\begin{array}{lll}1.75 & 15.00 & 125.00\end{array}$

$\begin{array}{lll}1.50 & 12.50 & 100.00\end{array}$

$1.75 \quad 15.00$

100.00

125.00

75.00

100.00

125.00

30.00

\section{BROADLEAVED EVERGREENS}

\section{ABELIA GRANDIFLORA}

2 to 3 feet

3 to 4 feet.

7.50

BUXUS SEMPERVIRENS (Boxwood)

12 to 15 inch B \& B

15 to 18 inch $\mathrm{B} \& \mathrm{~B}$

\section{DECIDUOUS SHRUBS}

Our shrubs are well grown as we have the best shrub grounds in the states. This stock is nice and bushy, is transplanted and will compare favorably with any stock on the market.

ALMOND FLOWERING (Amygdalus)

\section{Pink and White}

18 to 24 inch

10

3.00

4.00

5.00

to 3 feet

ALTHEA ROSE OF SHARON (Hibiscus)

Named varieties, Blue, Pink, Red and White

Those marked $*$ are $5 \mathrm{c}$ higher

12 to 18 inch

18 to 24 inch.

2 to 3 feet

3 to 4 feet.

4 to 5 feet

Amplissima, D. Red

Anemonaeflorus, Pink

*Ardens, Blue

Duchess De Brabant, D. Red

*Jeanne De Arc, D. White Lady Stanley, D. Pink
1.75

LaReine, D. Pink

$2.50 \quad 20.00$

100.00

125.00

175.00

$3.50 \quad 30.00$
Paconyfloris, D. Pink

Pompon Rouge, D. Red

Pulcherima, D. Red

*Purpurea Semi-Plena, D. Purple

*Totus Alba, S. White 


\section{DECIDUOUS SHRUBS (Continued)}

\section{ALTHEA ROSE OF SHARON (Hibiscus) (Continued) 10}

Tree Form

2 to 3 feet

3 to 4 feet

$t$ to 5 feet

$4.00 \quad 35.00$

5 to 6 feet

$4.50 \quad 40.00$

AMELANCHIER (Juneberry)

\section{Canadensis}

3 to 4 feet.

AMORPHA (False-Indigo)

Fruticosa (Indigo Bush)

2 to 3 feet

3 to 4 feet

\section{ARALIA}

Spinosa (Devil's Walking Stick)

18 to 24 inch.

2 to 3 feet.

3 to $t$ feet

Pentaphylla (Acanthopanox Pentaphyllum)

18 to 24 inch.

2 to 3 feet

3 to 4 feet

ARONIA (Chokeberry)

Arbutifolia (Red Chokeberry)

18 to 24 inch

2 to 3 feet.

\section{AZALEA}

Mollis (Chinese Azalea)

12 to 15 inch $\mathrm{B} \& \mathrm{~B}$

15 to 18 inch $\mathrm{B} \& \mathrm{~B}$

$1 \mathrm{I} / 2$ to 2 feet $B$ \& $B$.

\section{BARBERRY (Berberis)}

Thunbergii (Japanese Barberry)

12 to 15 inch 3 yr. heavy.

15 to 18 inch $3 \mathrm{yr}$. heavy.....

18 to $2 t$ inch $3 \mathrm{yr}$. heavy

$2 t$ to 30 inch $3 \mathrm{yr}$. heary.

30 to 36 inch 3 yr. heavy

\section{Hedge Grade}

10 to 12 inch 2 year

25.00

12 to 15 inch 2 year

Thunbergi Atropurpurea (New Red Leaved Barberry)

12 to 18 inch.

BUDDLEIA (Butterfly Bush)

Magnifica, Lilac Flowers

No. 1

\section{CALYCANTHUS (Sweet-Scented Shrub)}

\section{Floridus}




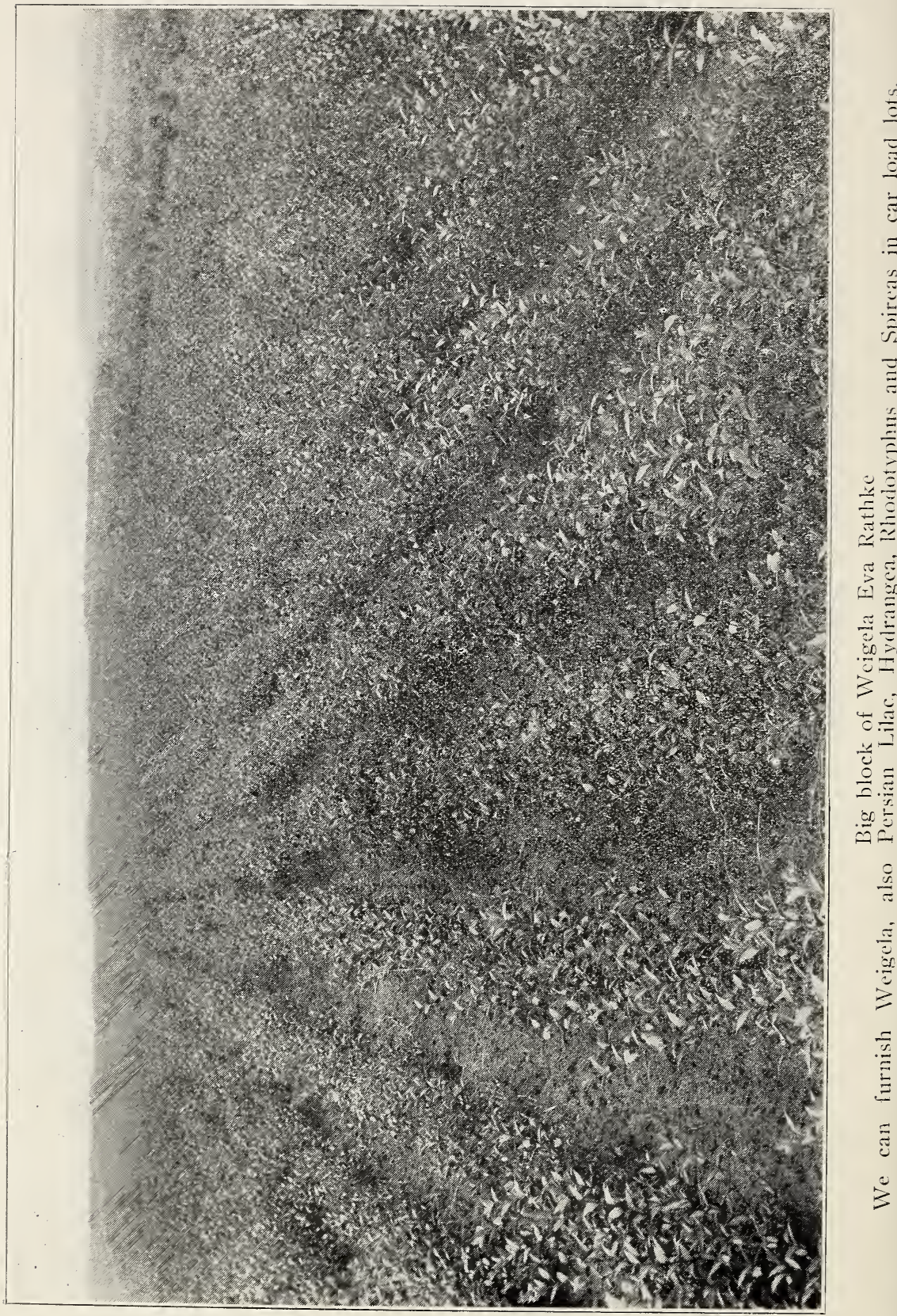




\section{DECIDUOUS SHRUBS (Continued)}

CARAGANA (Siberian Pea)

Arborescens

18 to 24 inch.

2 to 3 feet.

3 to \pm feet

CARYOPTERIS (Blue Spirea)

Mastacanthus

12 to 15 inch.

15 to 18 inch.

CEPHALANTHUS (Button Bush)

18 to 24 inch..

2 to 3 feet

3 to 4 feet

CERCIS (Red Bud)

Canadensis (American Judas)

2 to 3 feet

3 to 4 feet.

4 to 5 feet.

\section{CLETHRA}

Alnifolia (Sweet Pepper)

12 to 18 inch

18 to 24 inch.

2 to 3 feet.

$21 / 2$ to 3 feet

$5.50 \quad 50.09$
2.50

3.50

20.00

30.00

$10 \quad 100$

1000

$1.25 \quad 10.00$

$1.75 \quad 15.00$

$2.25 \quad 20.00$

$2.50 \quad 20.00$

$3.00 \quad 25.00$

$4.00 \quad 35.00$

$3.00 \quad 25.00$

$4.00 \quad 3 \% .50$

$5.00 \quad 45.00$

175.00

250.00

300.00

CORNUS (Dogwood)

Alba Siberica (Red Siberian)

12 to 18 inch

18 to 24 inch.

2 to 3 feet.

3 to 4 feet

1.75

2.50

5.00

4 to 5 feet.

15.00

20.00

30.00

100.00

150.00

Amomum (Sericea) Silky

2 to 3 feet.

$2.00 \quad 15.00$

3 to 4 feet

$2.50 \quad 20.00$

Elegantissima (Variegated Leaf)

18 to 24 inch.

2 to 3 feet

$2.70 \quad 25.00$

$3.75 \quad 3500$

3 to 4 feet.

$4.50 \quad 40.00$

Floridus (White Flowering)

$t$ to 5 feet.

$5.00 \quad 40.00$

\section{Floridus Rubra}

18 to 24 inch.

15.00

2 to 3 feet

22.50

3 to 4 feet.

30.00

Mascula (Cornelian Cherry)

2 to 3 feet.

$6.00 \quad 50.00$

Paniculata (Gray)

12 to 18 inch

18 to 24 inch.

2 to 3 feet.

$1.50 \quad 12.50$

3 to 4 feet

$2.50 \quad 20.00$

Spereth Aurea

2 to 3 feet. 


\section{DECIDUOUS SHRUBS (Continued)}

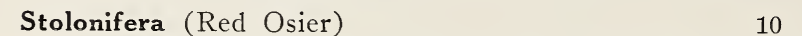

10

100

18 to 24 inch

$.80 \quad 7.00$

2 to 3 feet.

$1.00-8.00$

3 to 4 feet

$1.50 \quad 12.00$

4 to 5 feet.

$1.75 \quad 15.00$

Stolonifera Lutea (Yellow Twigged)

12 to 18 inch

18 to 24 inch.

2 to 3 feet

3 to 4 feet

4 to 5 feet.

$2.00 \quad 17.50$

$\begin{array}{lr}1.00 & 5.00\end{array}$

$1.50 \quad 10.00$

$1.75 \quad 15.00$

$2.50 \quad 20.00$

100.00

3.00

25.00

150.00

\section{COTONEASTER}

\section{Acutifolia}

18 to 24 inch

2 to 3 feet.

25.00

CYDONIA (Quince)

Japonica (Flowering Quince)

12 to 18 inch.

2.00

18 to 24 inch

2 to 3 feet

3.50

3 to 4 feet.

4.50

18.00

20.00

30.00

40.00

\section{DEUTZIA}

Candidissima (White)

2 to 3 feet

$2.00 \quad 15.00$

3 to 4 feet

$2.50 \quad 20.00$

Cranata (Pink)

18 to 24 inch

1.25

10.00

2 to 3 feet.

1.75

3 to 4 feet.

2.25

15.00

20.00

Gracilis (Dwarf White)

12 to 15 inch.

$1.50 \quad 12.00$

1.5 to 18 inch

$1.75 \quad 15.00$

18 to 24 inch.

$2.50 \quad 22.00$

\section{Gracilis Rosea}

18 to 24 inch

$2.50 \quad 20.00$

2 to 3 feet..

$3.00 \quad 25.00$

Lemoinei (Dwarf White)

12 to 18 inch

10.00

$1.75 \quad 15.00$

90.00

18 to 24 inch

2.50

22.00

125.00

24 to 30 inch.

$1.75 \quad 15.00$

2 to 3 feet.

3 to 4 feet..

$2.50 \quad 20.00$

\section{ELEAGNUS}

Angustifolia (Russian Olive)

12 to 18 inch

18 to 24 inch.

2 to 3 feet

2.50

3 to 4 feet.

4 to 5 feet..

\section{EUONYMUS}

40.00

Alatus (Winged Euonymus)

$1 \frac{1}{2}$ to 2 feet. 


\section{DECIDUOUS SHRUBS (Continued)}

EUONYMUS (Continued)

$10 \quad 100$

1000

Americanus (Brooke Euonymus)

18 to 24 inch...

2 to 3 feet

$\begin{array}{ll}1.75 & 15.00\end{array}$

3 to 4 feet

$3.50 \quad 30.00$

Europaeus (European Burningbush)

18 to 24 inch...

$4.50 \quad 40.00$

2 to 3 feet.

$2.50 \quad 20.00$

3 to 4 feet.

$3.50 \quad 30.00$

$5.00 \quad 45.00$

EXOCHORDA (Pearl Bush)

Grandiflora (Common Pearl Bush)

\begin{tabular}{|c|c|c|}
\hline 18 to 24 inch..................... & 2.00 & 15.00 \\
\hline 2 to 3 feet... & 3.00 & 25.00 \\
\hline 3 to & 4.00 & 35.00 \\
\hline 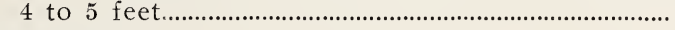 & 5.00 & 45.00 \\
\hline
\end{tabular}

\section{FORSYTHIA}

Intermedia (Border Forsythia)

12 to 18 inch.

18 to 24 inch.

1.00

7.50

10.00

50.00

2 to 3 feet..

1.20

$1 \tilde{.} .00$

3 to 4 feet.

1.75

2.50

20.00

4 to 5 feet.

$3.50 \quad 30.00$

Suspensa (Weeping)

2 to 3 feet.

2.50

20.00

3 to 4 feet..

3.00

25.00

Suspensa Fortunei (Golden Bell) Yellow flowers

12 to 18 inch.

1.00

7.00

50.00

18 to 24 inch.

1.25

2 to 3 feet..

10.00

75.00

Viridissima (Green Twigged)

12 to 18 inch.

18 to 24 inch.

1.75

2.50

.15 .00

$1.00 \quad 7.50$

$1.20 \quad 10.00$

2 to 3 feet.

1.75

3 to 4 feet.

2.50

15.00

20.00

HAMAMELIS (Witch Hazel)

Virginiana (Common Witch Hazel)

$1 \mathrm{r} / 2$ to 2 feet................................................................. 3.00

25.00

2 to 3 feet..

4.00

35.00

3 to 4 ieet.

$5.00 \quad 45.00$

HONEYSUCKLE BUSH (Lonicera)

Bella Albida (White)

Grandiflora Rosea. (Bright Pink)

Morrowii (White)

Tartarian White and Pink

Xylostene (Pink)

12 to 18 inch

18 to 24 inch.

1.00

6.00

50.00

1.20

10.00

75.00

1.75

15.00

100.00

3 to 4 feet

2.50

20.00

150.00

4 to 5 feet

3.00

25.00

200.00

Fragrantissima (Pink)

2 to 3 feet.

$2.20 \quad 18.00$

3 to 4 feet

3.00

25.00

Tartarian Red

2 to 3 feet

2.20

18.00

150.00

3 to 4 feet. 


\section{DECIDUOUS SHRUBS (Continued)}

\section{HYDRANGEA}

Arborescens Grandiflora (Hills of Snow)

12 to 18 inch

18 to 24 inch

1.75

15.00

2 to 3 feet

2.20

3.00

18.00

3 to 4 feet

Paniculata Grandiflora, guaranteed true type

12 to 18 inch.

18 to 24 inch

2 to 3 feet

2.50

3.20

30.00

3 to 4 feet

\section{Tree Form}

3 to 4 feet

4 to 5 feet

$8.00 \quad 75.00$

\section{HYPERICUM}

Assorted

12 to 18 inch

\section{KERRIA}

\section{Japonica Flora Plena}

18 to 24 inch.

2 to 3 feet

3 to 4 feet

KOLKWITZIA (New Shrub)

Flowers white flushed with pink

18 to 24 inch

LILAC (Syringa)

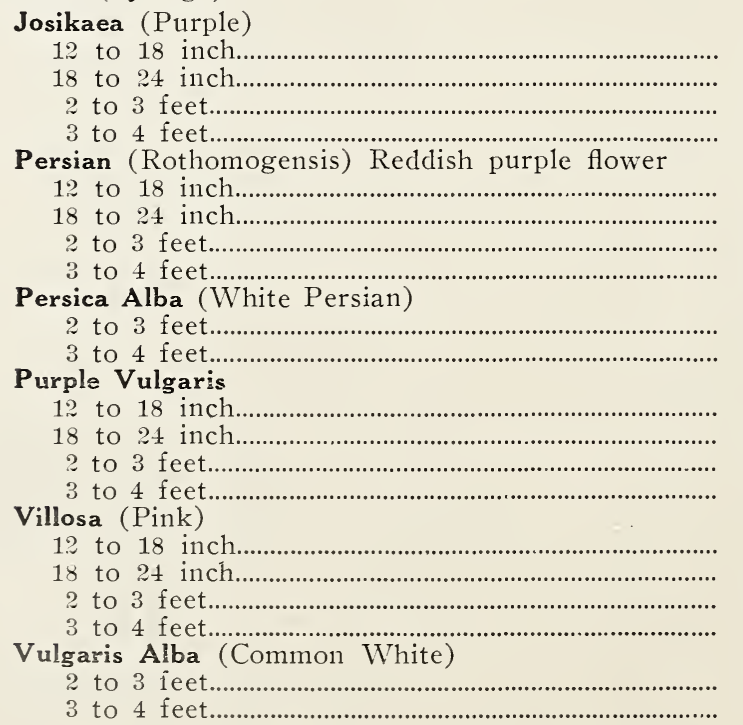




\section{DECIDUOUS SHRUBS (Continued)}

LILAC (Syringa) (Continued)

10

100

1000

Named varieties:

Chas. $\mathbf{X}$, sgl. reddish purple

Ludwig Spaeth, sgl. red

Marc Micheli, dbl. lilac

Michel Buchner, dbl. lilac

18 to 24 inch..

Pres. Grevy, db1. blue

Mme. Jacques Callot, db1. reddish violet

Mme. Lemoine, dbl. white

Marie LeGraye, sgl. white

2 to 3 feet.

$3.50 \quad 30.00$

3 to 4 feet

$5.00 \quad 45.00$

MAHONIA

12 to 18 inch $\mathrm{B} \& \mathrm{~B}$

$6.50 \quad 60.00$

18 to 24 inch B \& B

$10.00 \quad 75.00$

$12.50 \quad 100.00$

MALUS (Crab)

Aldanhemensis (New) Choice Variety

3 to 4 feet.

Bechtels

2 to 3 feet.

$4.50 \quad 35.00$

3 to 4 feet.

4 to 5 feet

$8.00 \quad 75.00$

Eleyi (New)

3 to 4 feet

$8.50 \quad 75.00$

Floribunda, White

Parkmanii, Pink

Pulchurima, Pink

Purpurea

Sargenti, Pale Straw Color

Ssheideckeri, Db1. Reddish Pink

Spectabilis, Pink

Toringo

2 to 3 feet.

3 to 4 feet.

MULBERRY HEDGE

3 to 4 feet

PEACH, Flowering

Amygdalus

3 to 4 feet..

$3.50 \quad 30.00$

PHILADELPHUS (Mockorange) White bloom

Aursa (Golden Foliage)

12 to 15 inch

$3.00 \quad 25.00$

15 to 18 inch

$3.50 \quad 30.00$

18 to 24 inch

$4.50 \quad 40.00$

Avalanche (Dwarf Mockorange)

12 to $18 \mathrm{inch}$

$1.80 \quad 15.00$

18 to 24 inch

$2.50 \quad 20.00$

24 to 30 inch

$3.00 \quad 25.00$

30 to 36 inch

$3.50 \quad 30.00$

Coronarius (Sweet Mockorange)

18 to 24 inch.

$1.50 \quad 10.00$

75.00

2 to 3 feet.

1.70

15.00

100.00

3 to 4 feet

2.20

20.00

4 to 5 feet

3.00 25̃.00

Grandiflora (Big scentless Mockorange)

12 to 18 inch..

18 to 24 inch.

$.80 \quad 7.00$

150.00

2 to 3 feet

1.20

10.00

50.00

3 to 4 feet

1.75

15.00

75.00

2.50

20.00

Lemoine (Dwarf Mockorange)

12 to 18 inch

$2.00 \quad 15.00$

18 to 24 inch

$2.50 \quad 20.00$

24 to 30 inch

$3.00 \quad 25.00$ 


\section{DECIDUOUS SHRUBS (Continued)}

PHILADELPHUS (Mockorange) White bloom (Continued)

Mont Blanc (Dwarf Double Flowering Mockorange)

12 to 18 inch.................................................................... 3.50

18 to 24 inch......................................................................... 4.00

100

1000

2 to 3 feet

$4.50-40.00$

Nivalis (Snowbank Mockorange)

18 to 24 inch.

$1.50 \quad 10.00$

2 to 3 feet

$1.70 \quad 15.00$

3 to 4 feet

$2.20 \quad 20.00$

4 to 5 feet

$3.00 \quad 25.00$

Virginal (Double White Large Flower)

18 to 24 inch...

2 to 3 feet

3 to 4 feet

$3.00 \quad 25.00$

$4.00 \quad 35.00$

175.00

5.50

50.00

225.00

350.00

PHILADELPHUS, New Varieties

Those marked * are large flowering

\section{Albatre}

18 to 24 inch

2 to 3 feet...

$4.00 \quad 35.00$

\section{*Banniere}

18 to 24 inch.

2 to 3 feet

3 to 4 feet

\section{Dane Blanche}

18 to 24 inch.

2 to $2 \mathrm{I} / 2$ feet

$4.00 \quad 35.00$

\section{*Favorite}

18 to 24 inch

$3.50 \quad 25.00$

2 to 3 feet

$4.00 \quad 35.00$

\section{*Girandole}

18 to 24 inch................................................................ $3.50 \quad 25.00$

\section{Glacier}

18 to 24 inch.

2 to 3 feet

\section{*Norma}

18 to 24 inch.

2 to 3 feet

25.00

$4.00 \quad 35.00$

3 to 4 feet

4.50

40.00

Ophelia, Dwarf

18 to 24 inch.

$3.50 \quad 25.00$

2 to 3 feet.

$4.00 \quad 35.00$

\section{Pavillion Blanc}

18 to 24 inch.

2 to 3 feet...

\section{*Pyramidal}

18 to 24 inch

2 to 3 feet

3 to 4 feet

\section{POTENTILLA}

\section{Fruticosa}

18 to 24 inch

2 to 3 feet. 


\section{DECIDUOUS SHRUBS (Continued)}

PRIVET (Ligustrum)

Amour River North Privet Hardy (Amurense)

12 to 18 inch 2 and $3 \mathrm{br}$.

12 to 18 inch heavy br.

18 to 24 inch heavy br.

2 to 3 feet heavy br.

3 to 4 feet 4 br. up.

California (Ovalifolium)

12 to 18 in. 4 br. up

18 to 24 in. 4 br. up

2 to 3 feet 4 br. up

3 to 4 feet.

Ibota (Chinese) Spreading

12 to 18 in. 4 br. up.

18 to 24 in. 4 br. up

2 to 3 feet 4 br. up.

3 to 4 feet 4 br. up

Regel's (Ibota Regelianum) true type from cuttings 12 to 18 inch.

18 to 24 inch.

24 to 30 inch.

30 to 36 inch.

\section{PRUNUS}

Pissardii (Budded on Plum)

2 to 3 feet.

3 to 4 feet

4 to 5 feet

5 to 6 feet

Pumila (Rocky Mt. Cherry)

12 to 18 inch.

18 to 24 inch.

2 to 3 feet

3 to 4 feet

Triloba (Double-Flowering Plum) Budded on Plum

18 to 24 inch..

2 to 3 feet.

3 to 4 feet

4 to 5 feet.

RHAMNUS (Buckthorn)

Cathartica (Common Buckthorn)

18 to 24 inch

2 to 3 feet.

\section{Frangula}

3 to 4 feet

2 to 3 feet.

3 to 4 feet.

\section{RHODOTYPHUS}

\section{Kerroides}

12 to 18 inch

18 to 24 inch

2 to 3 feet.

3 to 4 feet.

\section{RHUS}

Aromatica (Fragrant Sumach)

18 to 24 inch

2 to 3 feet.
10

$\begin{array}{rr}100 & 1000 \\ & \\ 4.50 & 35.00 \\ 5.00 & 40.00 \\ 7.50 & 55.00 \\ 10.00 & 70.00 \\ 12.00 & 100.00 \\ & \\ 2.50 & 20.00 \\ 3.00 & 25.00 \\ 4.50 & 40.00 \\ 6.00 & 55.00 \\ & \\ 5.00 & \\ 6.00 & \\ 8.00 & \\ 14.00 & \\ & \\ 10.00 & 70.00 \\ 12.00 & 100.00 \\ 15.00 & 125.00 \\ 20.00 & 150.00\end{array}$

3.00

25.00

35.00

40.00

50.00

1.00

1.25

1.75

2.50

$3.00 \quad 25.00$

$3.50 \quad 30.00$

$4.50 \quad 40.00$

$6.50 \quad 60.00$

$1.50 \quad 10.00$

$2.00 \quad 15.00$

$2.50 \quad 20.00$

$2.00 \quad 15.00$

$2.50 \quad 20.00$

2.00

12.50

$2.50 \quad 20.00$

$3.25 \quad 25.00$

$3.75 \quad 35.00$

200.00

250.00 


\section{DECIDUOUS SHRUBS (Continued)}

\begin{tabular}{|c|c|c|c|}
\hline $\begin{array}{l}\text { RHUS (Continued) } \\
\text { Copalina }\end{array}$ & 10 & 100 & 1000 \\
\hline is to 24 inch......................... & 2.00 & 15.00 & \\
\hline 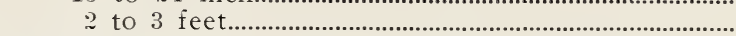 & 2.50 & 20.00 & \\
\hline Cotinus (Purple Fringe or Common Smoketree) & & & \\
\hline 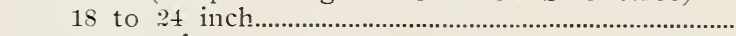 & 3.50 & 30.00 & \\
\hline 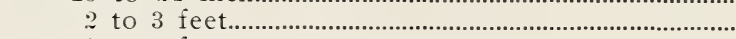 & 5.50 & 50.00 & \\
\hline 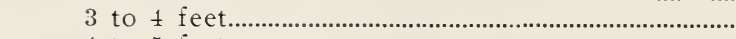 & 6.50 & 60.00 & \\
\hline 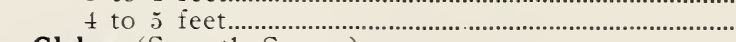 & 8.00 & 75.00 & \\
\hline Glabra (Smooth Sumac) & & & \\
\hline 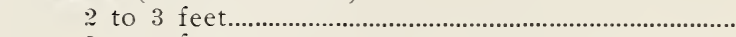 & 2.00 & 15.00 & \\
\hline 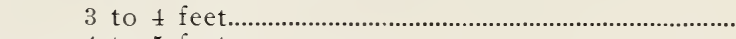 & 2.50 & 20.00 & \\
\hline 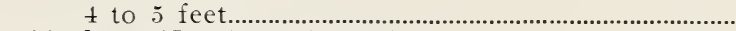 & 3.00 & 25.00 & \\
\hline Typhina (Staghorn Sumac) & & & \\
\hline 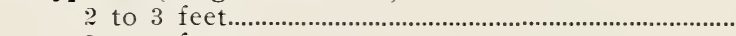 & 2.00 & 15.00 & \\
\hline 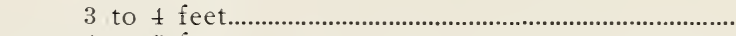 & 2.50 & 20.00 & \\
\hline \pm to 5 feet & 2.75 & 25.00 & \\
\hline Typhina Laciniata (Fern-leaf Sumac) & & & \\
\hline 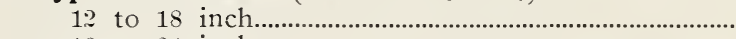 & 1.40 & 10.00 & \\
\hline 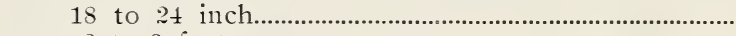 & $1 . ; 0$ & 12.00 & \\
\hline 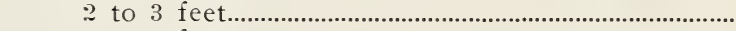 & 2.50 & 20.00 & \\
\hline 3 to 4 feet........... & 3.00 & 25.00 & \\
\hline 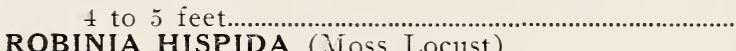 & 3.50 & 30.00 & \\
\hline 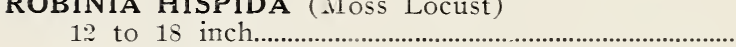 & 2.00 & 15.00 & \\
\hline 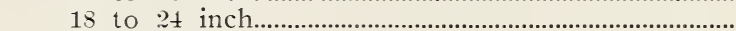 & 3.00 & 25.00 & \\
\hline 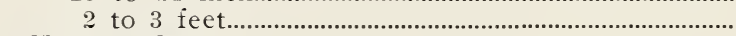 & 4.00 & 35.00 & \\
\hline Top Worked & & & \\
\hline 3 to 4 feet.............. & 12.50 & 100.00 & \\
\hline 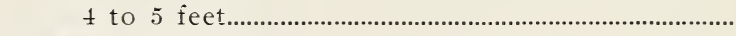 & 15.00 & 125.00 & \\
\hline $\begin{array}{l}\text { RUBUS (Raspberry) } \\
\text { Odoratum (Flowering Raspberry) }\end{array}$ & & & \\
\hline 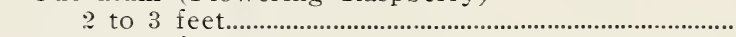 & 3.00 & 25.00 & \\
\hline 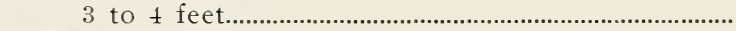 & 3.50 & 30.00 & \\
\hline $\begin{array}{l}\text { SAMBUCUS (Elder) } \\
\text { Acutifolia (Cut-Leaf Elder) }\end{array}$ & & & \\
\hline 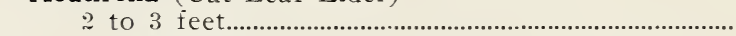 & 1.75 & 15.00 & \\
\hline 3 to 4 feet................... & 2.50 & 20.00 & \\
\hline Canadensis (Common Elder) & & & \\
\hline 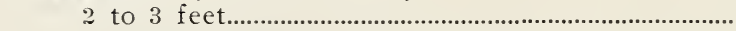 & $1 . \pi 5$ & 15.00 & \\
\hline …… & 2.50 & 20.00 & \\
\hline Nigra Aurea (Golden Elder) & & & \\
\hline 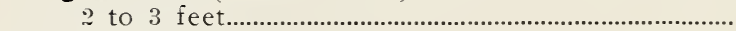 & 2.25 & 17.50 & \\
\hline 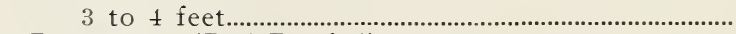 & 2.50 & 2.2 .50 & \\
\hline Racemosus (Red Berried) & & & \\
\hline 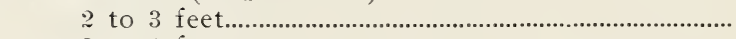 & 2.50 & 20.00 & \\
\hline 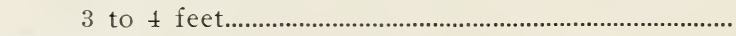 & 3.00 & 25.00 & \\
\hline SPIRAEA (Spirea) & & & \\
\hline Anthony Waterer (Dwarf Crimson Everblooming) & & & \\
\hline 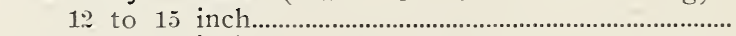 & 1.75 & 12.00 & \\
\hline 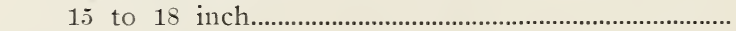 & 2.00 & 16.00 & \\
\hline 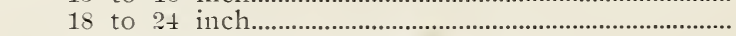 & 2.50 & 20.00 & \\
\hline 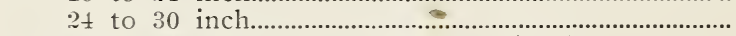 & 3.50 & 30.00 & \\
\hline Arguta (White flowers, feathery foliage) & & & \\
\hline 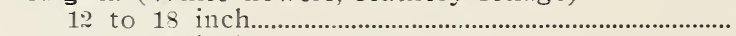 & 1.50 & 10.00 & \\
\hline 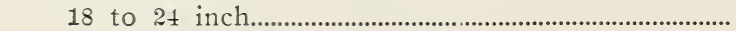 & 1.75 & 12.00 & 100.00 \\
\hline 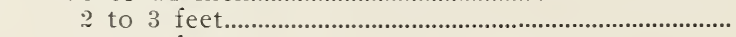 & 2.25 & 18.00 & 120.00 \\
\hline 3 to 4 feet.......................... & 3.00 & 25.00 & 150.00 \\
\hline
\end{tabular}




\section{DECIDUOUS SHRUBS (Continued)}

SPIRAEA (Spirea) (Continued)

$10 \quad 100$

1000

Bethlemanii (Pink)

12 to 18 inch.

1s 1024 inch.

$1.20 \quad 10.00$

2 to 3 feet.

$1.10 \quad 15.00$

3 to 4 feet..

$2.20 \quad 20.00$

Billardii (Pink)

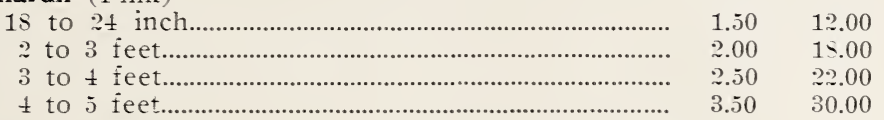

Billardii (White)

1: to 15 inch

18 to $2 \pm$ inch.

2 to 3 feet.

3 to 4 feet.

Callosa Alba (Dwarf White)

12 to 15 inch

15 to $1 \mathrm{~s}$ inch.

18 to $2 \pm$ inch.

Callosa Rosea (Pink)

12 to 18 inch.

18 to 24 inch.

2 to 3 feet.

3 to 4 feet.

$3.00 \quad 25.00$

\section{Douglassi}

1s to 24 inch

$1.50 \quad 12.00$

2 to 3 feet.

15.00

Froebeli (Dwarf Red)

12 to 19 inch

18 to $2 \pm$ inch

24 to 30 inch.

1.15

30 to 36 inch.

Opulifolia (Ninebark)

18 to 24 inch..

2 to 3 feet

3 to \pm feet.

$1 .: 0$

20.00

150.00

\pm to 5 feet

2.20

25.00

200.00

Opulifolia Aurea (Golden Ninebark)

1:2 to 15 inch.

18 to 24 inch

2 to 3 feet.

$1 . i 0$

3 to 4 feet.

2.20

15.00

20.00

Pranifolia, White flowers

15 to 24 inch.

2 to 3 feet.

\section{Reevesiana}

15 to 24 inch

2 to 3 feet

3 to \pm feet.

$2.50 \quad 20.00$

Salcifolia Alba, White Flowers 


\section{DECIDUOUS SHRUBS (Continued)}

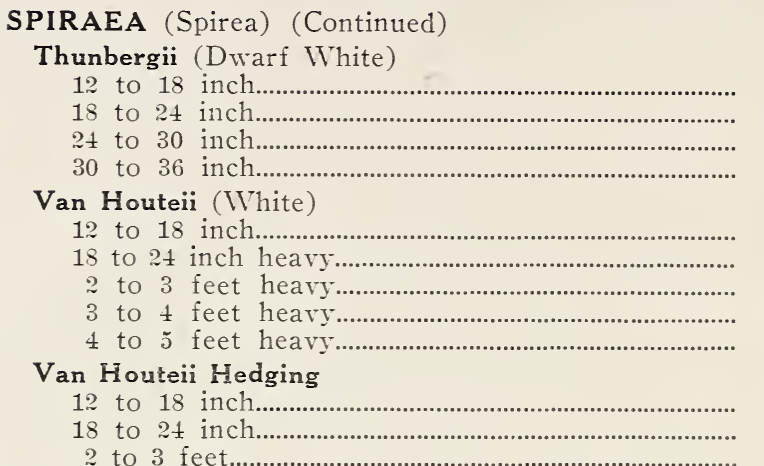

10

\section{STEPHENANDRA}

Flexuosa (Cutleaf Stephenandra)

12 to 18 inch

18 to $2 \frac{1}{2}$ inch

24 to 30 inch

SYMPHORICARPUS (Snowberry)

Racemosus and Mollis (White)

12 to 18 inch

18 to 24 inch

2 to 3 feet.

3 to 4 feet.

Vulgaris (Red)

18 to 24 inch.

2 to 3 feet

3 to 4 feet.

\section{TAMARIX}

Hispida Aestavalis (Red Flower)

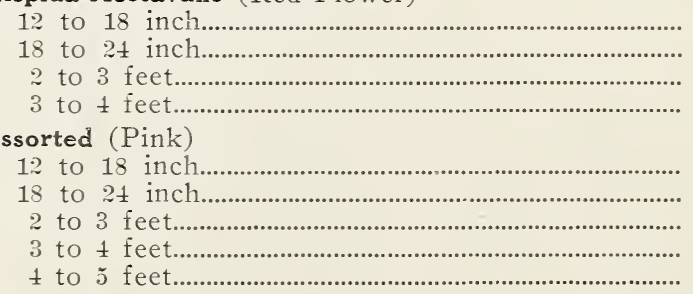

\section{VIBURNUM}

\section{Americanum}

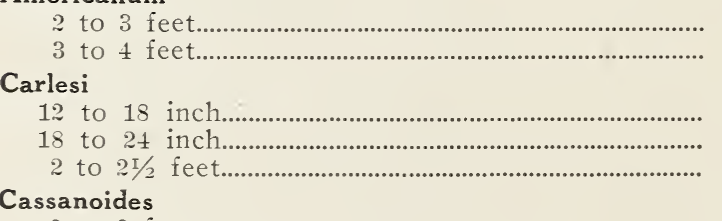




\section{DECIDUOUS SHRUBS (Continued)}

VIBURNUM (Continued)

$10 \quad 100$

1000

Dentatum (Arrow Wood)

12 to 18 inch

$1.25 \quad 10.00$

18 to 24 inch

$2.20 \quad 15.00$

2 to 3 feet.

$2.50 \quad 20.00$

3 to 4 ieet.

$3.00 \quad 25.00$

4 to 5 feet.

$3.75 \quad 35.00$

200.00

Lantana (IVayfaring tree)

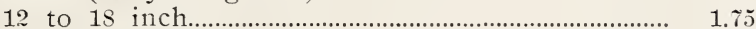

2 to 3 feet $\quad 4.00$

3 to 4 feet

35.00

$5.00 \quad 45.00$

Lentago (Sheepberry)

12 to 18 inch.

$2.00 \quad 15.00$

18 to $2 \pm$ inch.

$2.50 \quad 20.00$

2 to 3 feet

$3.50 \quad 30.00$

3 to 4 feet

$4.50 \quad 40.00$

Opulus (High Bush Cranberry)

12 to 18 inch well br.....

18 to 24 inch..

2 to 3 feet

3 to 4 feet

$3.00 \quad 25.00$

$4.00 \quad 35.00$

$5.00 \quad 45.00$

Opulus Sterilis (Common Snowbal1)

12 to 18 inch..

18 to 24 inch.

$2.00 \quad 1 \% .50$

2 to 3 feet.

$3.00 \quad 25.00$

3 to 4 feet.

$4.00 \quad 35.00$
5.00

$5.00 \quad 45.00$

\section{Plicatum}

18 to 24 inch

$4.00 \quad 35.00$
0.00

2 to 3 feet..

$5.00 \quad 45.00$

\section{Prunifolium}

18 to 24 inch

\section{Tomentosum}

12 to 18 inch

18 to 24 inch.

2.15

2 to 3 feet.

WEIGELA (Diervilla)

Abel Carrier

2 to 3 feet.

3 to 4 feet.

Candida (White)

3 to 4 feet.

Eva Rathke (Red)

18 to 24 inch

2 to 3 feet.

3 to + feet.

Florabunda (Red)

18 to 24 inch

2 to 3 feet.

Variegata (Pink Flowers, variegated leaves)

12 to 18 inch. 


\section{DECIDUOUS SHRUBS (Continued)}

WEIGELA (Diervilla) (Continued)

10

100

1000

Weigela (Assorted)

Amabilis, Des Boise, Gustav Mallet, Hendersonia,

Lemoine, Lutea, Madam Tellier, Rosea

12 to 18 inch well br.

60.00

18 to 24 inch well br.

1.50

10.00

2 to 3 feet

1.75

3 to \pm feet

15.00

2.50

20.00

4 to 5 feet

ZANTHOXYLUM (Prickly-Ash)

Americanum (Common Prickly-Ash)

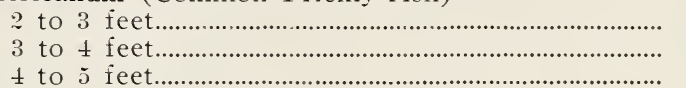

VINES AND CREEPERS

\section{AMPELOPSIS}

Engelmanni (Engelmann Ivy)

2 year 3 year

Quinquefolia (Woodbine or Virginia Creeper)

2 year

Veitchii (Japanese Ivy)

2 year tops cut back to $12 \mathrm{in}$

2 year No. 1

3 year No. 1

3 year XX

ARISTOLOCHIA (Dutchman Pipe)

Sipho (Grafted) True Type

2 year No. 1

3 year No. 1

4.00

35.00

250.00

\section{BIGNONIA}

Radicans (Trumpet Creeper)

2 year No. 1

3 year No. 1 .

$3.50 \quad 30.00$

$4.50 \quad 40.00$

$2.00 \quad 18.00$

$2.25 \quad 22.00$

\section{CELASTRUS (Bittersweet)}

Scandens

2 year No. 1

$1.75 \quad 15.00$

3 year No. 1

CLEMATIS (Large Flowering)

\section{Baron Villard (Pink)}

Henryii (White)

Jackmanii (Blue)

Mde. Andre (Red)

Ramona (Pink)

2 year No. 1

2 year Meditim

Paniculata (White)

2 year No. 1 ....

2 year Medium..

\section{Radicans}

$$
3 \text { year No. } 1 .
$$




\section{VINES AND CREEPERS (Continued)}

\begin{tabular}{|c|c|c|c|}
\hline HONEYSUCKLE CLIMBING & 10 & 100 & 1000 \\
\hline Aurea (Reticulata) Variegated Leaf & & & \\
\hline 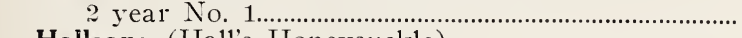 & 2.500 & 20.00 & \\
\hline Halleana (Hall's Honeysuckle) & & & \\
\hline 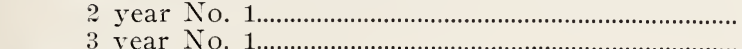 & 2.00 & 15.00 & 100.00 \\
\hline Red Coral & 2.50 & 20.00 & \\
\hline 2 year & 2.00 & 17.50 & \\
\hline 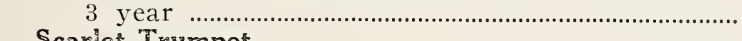 & 2.50 & 20.00 & \\
\hline Scarlet Trumpet & & & \\
\hline 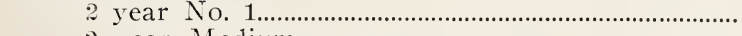 & 1.75 & 15.00 & \\
\hline 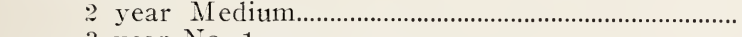 & 1.50 & 12.00 & \\
\hline 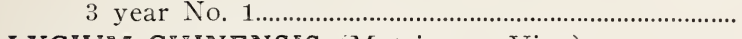 & 2.50 & 20.00 & \\
\hline $\begin{array}{l}\text { LYCIUM CHINENSIS (Matrimony Vine) } \\
\text { Chinese }\end{array}$ & & & \\
\hline 2 year No. $1 \ldots . .$. & 2.00 & 15.00 & \\
\hline 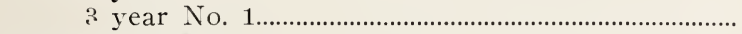 & 2.50 & 20.00 & \\
\hline POLYGONUM & & & \\
\hline Auberti (Silver Lace Vine) & & & \\
\hline 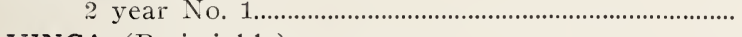 & 4.50 & 40.00 & \\
\hline VINCA (Periwinkle) & & & \\
\hline 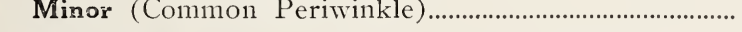 & 1.50 & 10.00 & 90.00 \\
\hline WISTERIA & & & \\
\hline Chinensis Seedlings, Purple or white Flowering & & & \\
\hline 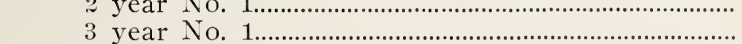 & 2.00 & $\begin{array}{l}15.00 \\
17.50\end{array}$ & $\begin{array}{l}100.00 \\
125.00\end{array}$ \\
\hline Chirensis, from grafts and layers & & & \\
\hline Purple Flowering & & & \\
\hline 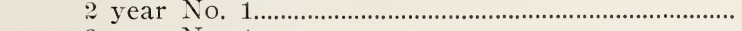 & 3.50 & 30.00 & \\
\hline 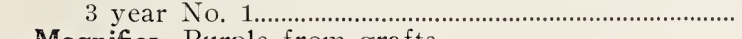 & 4.50 & 40.00 & \\
\hline Iagnifica, Purple from grafts & & & \\
\hline 2 year No. 1........................................ & 2.50 & 20.00 & \\
\hline 1 1................................ & 3.00 & 25.00 & \\
\hline
\end{tabular}

\section{CLIMBING ROSES}

\section{SPECIAL PRICES IN THOUSAND LOTS OR MORE}

AMERICAN PILLAR (Red)

2 year No. 1

$10 \quad 100$

$2.25 \quad 18.00$

2 year No. $1 \frac{1}{2}$

$1.75 \quad 15.00$

2 year No. 2

$1.50 \quad 12.00$

AVIATEUR BLERIOT (Yellow)

2 year No.

2 year No. $1 \%$

$2.25 \quad 20.00$

2 year No. 2

\section{BLUE RAMBLER}

2 year No. 1

$2.25 \quad 20.00$

CLIMBING AMERICAN BEAUTY (Red)

2 year No.

2 year No. $1 \frac{1}{2}$

2 year No.

$\begin{array}{ll}2.20 & 20.00 \\ 1.75 & 15.00\end{array}$

CLIMBING BABY ORLEANS (Dark Pink Everblooming)

2 year No. 1

2 year No. 2 


\section{CLIMBING ROSES (Continued)}

CLIMBING BABY RAMBLER (Red)

2 year No. 1

2 year No. $11 / 2$

2 year No. 2

CRIMSON RAMBLER (Red)

2 year No. 1

2 year No. 1, I/2.

2 year No. 2

DR. E. M .MILLER (Pink)

2 year No. 1

2 year No. $1 \frac{1}{2}$.

2 year No. 2

DR. VAN FLEET (Flesh Pink)

2 year No. 1.

2 year No. $1 \frac{1}{2}$.

2 year No. 2

DOROTHY PERKINS (Pink)

2 year No. 1

2 year No. $1 \mathrm{I} / 2$

2 year No. 2

EMPRESS OF CHINA (Pink)

2 year No. 1

2 year No. $1 \frac{1}{2}$

2 year No. 2

EUGENE JACQUET (Red)

2 year No. 1

2 year No. $1 \frac{1}{2}$.

2 year No. 2

EXCELSA (Red Dorothy Perkins)

2 year No. 1

2 year No. $11 / 2$.

2 year No. 2

FLOWER OF FAIRFIELD (Red Everblooming)

2 year No. 1

2 year No. $1 \frac{1}{2}$

2 vear No. 2

GARDENIA (Yellow)

2 year No. 1

2 vear No. 11/2.

2 year No. 2

GRAF ZEPPELIN (Pink)

2 year No. 1

2 year No. 11/2.

2 year No. 2

HIAWATHA (Red with white eye)

2 year No. 1

2 year No. $1 \frac{1}{2}$

2 year No. 2

LADY GAY

2 year No. 1

MARY WALLACE (Rose Pink with salmon base)

2 year No. 1

2 year No. 11/2

2 year No. 2

\section{0}

100

20.00

$1.15 \quad 15.00$

$1.50 \quad 12.00$

$2.50 \quad 20.00$

$1.15 \quad 15.00$

$1.50 \quad 12.00$

2. 0025.00

$2.25 \quad 20.00$

$1.15 \quad 15.00$

$3.00 \quad 25.00$

$2.50 \quad 20.00$

$1.50 \quad 12.00$

2.00

1.50

1.25

1.50

1.20

1.00

3.00

2.50

2.00

2.00

1.50

1.25

2.50

2.00

1.15

2.50

2.00

1. .5

2. 10

2.25

1.75

15.00

10.00

8.00

100.00

80.00

60.00

12.00

10.00

ก.50

25.00

20.00

15.00

15.00

10.00

8.00

20.00

15.00

12.00

175.00

120.00

100.00

20.00

1..00

15.00

25.00

20.00

15.00

1.75

1.50

15.00

1.00

12.50

8.50

2.50

20.00

3.00

25.00

2.50

20.00

$1.75 \quad 15.00$ 


\section{CLIMBING ROSES (Continued)}

METEOR (Red)

2 year No.

2 year No. $11 / 2$.

PAUL'S SCARLET (Dark Red)

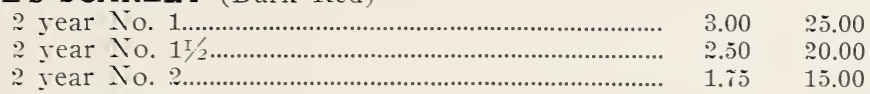

\section{PINK RAMBLER}

2 vear Jo 1

2 vear No. 1 I

2 year No. 2

ROSERIE (Red Tousandschon)

3 rear No.

2 rear No. 1

2 year No. $1 \frac{1}{2}$.

2 jear No. 2

$1.75 \quad 15.00$

$1.50 \quad 12.00$

ROSA WICHURIANA (White) Memorial Rose

$\approx$ year No.

$2.00 \quad 1 \% .50$

150.00

SEVEN SISTERS (Pink)

2 year No. 1

SILVER MOON (White)

2 year No. 1

TAUSENDSCHON (Pink)

2 year No. 1

2 year No.

WHITE DOROTHY PERKINS

2 year No. 1

2 rear No.

BUSSH ROSES

HYBRID PERPETUAL

2 year No. 1

2 year No. 1

Anne Diesbach (Pink)

Capt. Hayward (Bright Scarlet)

Clio (Pink)

Earl of Dufferin (Velvety Crimson)

Frau Karl Druschki (White)

General Jacqueminot (Red)

Geo. Alyrends (Pink)

Hugh Dickson (Brilliant Crimson)

J. B. Clarke (Scarlet)

John Hopper (Rose Pink)

Jubilee (Red)

M. P. Wilder (Crimson)

Magna Charta (Pink)

Mde. Plantier (White)

Mrs. John Laing (Pink)

Pail Neyron (Pink)

Persian Yellow

Ulrich Brunner (Red) 


\section{BUSH ROSES (Continued)}

TEA AND HYBRID TEA (Everblooming)

Those marked with * are 5c higher.

2 year No. 1

2 year No. $1 \frac{1}{2}$

Betty (Light Pink)

Capt. Christy (Delicate Flesh Pink)

Caroline Testout (Pink)

Claudia Pernet (Yellow)

Columbia (Pink)

* Constance (Golden Yellow)

*Dunlap (Pink)

Edward Mawley (Deep Velvety Crimson)

Etoile De France (Velvety Crimson)

*Francis Kruger (Yellow)

Francis Scott Key (Deep even Red)

Gruss an Teplitz (Red)

J. L. Mo=k (Deep Pink)

Kaiserina Augusta Victoria (White)

*Lady Hillington (Deep Apricot Yellow)

LaFrance (Pink)

Lolita Armour (Red)

*Los Angeles (Gold flushed with pink)

Luxemburg (Yellow)

*Mme. Butterfly (Yellow)

*Mde. Edouard Herriott (Copper Yellow)

Pink Killarney

Pink Radiance

Red Radiance

Royal Red

Ruga (Red)

*Soleil d'Or (Yellow)

*Sunburst (Rich Yellow, shaded coppery orange)

White Killarney

*Wm. F. Dreer (Silvery Yellow)

BABY RAMBLER (Dwarf)

2 year No.

2 year XX heavy forcing grade.

2 year No. $1 \frac{1}{2}$

Baby Catherine Zeimet (White)

Baby Dorothy (Pink)

Baby Edith Caville (Red)

Baby Erra Teschendorf (Dark Red)

Baby Ideal (White)

Baby Mme. Levavasseur (Red)

Baby Orleans (Pink)

Baby Triomphe Orleannais (Red)

\section{PRAIRIE ROSES}

Rosa Blanda and Setigera

2 year No. 1

2 year No. 1

3 year No. 1

$2.50 \quad 20.00$

Sweet Briar

$3.50 \quad 30.00$

Rubiginosa (Pink)

2 year No. 1 


\section{BUSH ROSES (Continued)}

ROSA RUGOSA

Red

White

2 vear No. 1

2 year No. $1 \frac{1}{2}$

3 year No. 1

2 vear No. 1

2 year No. $11 / 2$

3 year No. 1
2.00

1.75

2.50

3.00

2.50

4.00

ROSA RUGOSA (Double)

Named Varieties

Belle Poitevine (Pink)

Conrad F. Meyer (Pink)

Rosa Hansa (Red)

Sir Thomas Lipton (White)

2 year No.

2 year No. 1 I

$\begin{array}{ll}2.25 & 20.00 \\ 2.00 & 1 \% .50\end{array}$

2 year No. 2

Grootendorst (Red Everblooming)

2 year No. 1

Hugonis (Golden)

$3.50 \quad 30.00$

2 year No. 1

$4.50 \quad 40.00$

\section{HARDY PERENNIALS}

ACHILEA (Yarrow)

Boule de Neige (White).

Millefolium Rosium (Red)

The Pearl (Thite)...

Tomentosum (Yellow)

25.00

20.00

30.00

ACONITUM (Monkshood)

Fischerii (Azure Monkshood)

AGROSTEMMA (Champion)

Coronaria (Bright Crimson)

ALYSSUM

Saxatile Compactum (Dwari Goldentuft)...

ANEMONE

Japonica (Queen Charlotte) Pink....................................

ANTHEMIS (Camomile)

Tinctoria (Yellow Flower)

ARABIS (Rockcress)

Alpinum (White) 2 year No. 1

ARTEMISIA (Wormwood)

Lactiflora (White Mugwort)

AQUILEGIA (Columbine)

California Hybrids (Yellow and Orange)

Canadensis (Red and Yellow)

Chrysantha (Yellow)

Long Spurred Hybrids (Mrs. Scott Elliott) Blue Shades

Long Spurred Pink

$1.00 \quad 6.00$

Nivae Grandiflora (Mixed Colors) 


\section{HARDY PERENNIALS (Continued)}

ASTER

10

100

1000

Alpinus (Mixed)

$1.50 \quad 10.00$

Climax (Lavender)

$1.50 \quad 10.00$

Climax (White)

$1.50 \quad 10.00$

Feliham (Blue)

$1.50 \quad 10.00$

Perennial Mixed

$1.00 \quad 6.00$

St. Egwin (Soft Pink).......................................................... $1.50 \quad 10.00$

Stokesia (Corn Flower Asters)......................................... $1.50 \quad 10.00$

ASTILBE Arendsi (Perennial Spirea)

America (Lilac color)

Gladstone (White)

Peach Blossom (Pink)

Queen Alexander (Deep Pink)

BACCONIA (Plume Poppy)

Cordata

3.00

25.00

200.00

3.00

3.00

25.00

200.00

3.00

25.00

200.00

$25.00 \quad 200.00$

BAPTISTE (False Indigo)

Australis

10.00

1.50

10.00

BELLIS PERENNIS (English Daisy)

Snowball (Pure White).

$1.00 \quad 6.00$

BOLTONIA (False Chamomile)

Asteroides (White)

Latisquama (Lavender-Pink)

CAMPANULA (Canterberry Bell)

Carpatica (Blue)

Persicifolia Alba (White)

1.50

10.00

Persicifolia Grandiflora (Blue) Mixed

CARNATION

Grenadin (Red, Dark Red, White, Pink, or Yellow)

1.00

6.00

CHELONE

Lyoni (Shell Flower) Purplish Red Flowers.

1.00

6.00

CHRYSANTHEMUM (Hardy)

Golden Queen (Yellow)

Indian (Red)

Old Homestead (Pink)

Victoria (White)

1.50

9.00

COREOPSIS (Tickweed)

Lanciolata (Yellow)

\section{DAISY}

Arctic Daisy (Arcticum)

Shasta Alaska (White with Brown Eye)

DELPHINIUM (Larkspur)

Belladonna (Light Blue)

Bellamosa (Dark Blue)

Gold Medal Hybrids (Shades of Blue).

Indigo (New)

New English Hybrids (Mixed Colors).

\section{DIANTHUS}

Barbatus, Newport Pink.

Sweet William

White

Mixed, all colors

1.00

6.00

40.00

1.00

ז.00

1.00

6.00

40.00

1.00

6.00

40.00

1.00

7.00

1.00

6.00

$1.00 \quad 8.00$

$1.50 \quad 7.00$

Caesius (Dark Red Long Stems)..... 


\section{HARDY PERENNIALS (Continued)}

DIANTHUS (Continued) 10

Double Rose

Fireball (Red)

Her Majesty (Double White)

Holborn Glory (Various).

Latifolius (Double Dark Red).

Pink Beauty

Plumaris (Garden Pink).

Salmon Queen

DICENTRA

Eximia (Fringed Everblooming Bleedingheart).......... Speciabilis (Bleeding Heart).

DICITALIS (Fox Glove)

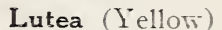

Purpurea

Mixed

EULALIA (Hardy Grasses)

Japonica Variegata

Zebrina

EUPHORBIA (Spurge)

Corcllata (Thite Flowering Spurge).

FERNS (Hardy) Named Varieties

Adiantum Pedatum (Vaidenhair Fern)

Aspidium Cristatum (Evergreen Fern).

Aspidium Goldiana (Goldie's Wood Fern).....................

Aspidium Spinulosum (Tood Feri1)...

Asplenium Felix Faemina (Lady Fern).

Asplenium shelypteris (Silver Spleenworth).

Dryopteris thelypteris (Shield Fern).

Onoclea sensibilis (Sensitive Fern)......

Oncclea strutiopteris (Ostrich Fern)

Osmunda cinnamomea (Cinnamon Fern)

Csmunda claytoniana (Interrupted Fern)

FERNS (Hardy)

Our Assortment

1.20

1.20

1.75

1.20

1.20

1.20

1.00

1.20

3.00

4.00

20.00

30.00

1.00

¿.00

1.00

1.00

.00

¿.00

2.00

2.00

$1 \% .50$

17.50

1.50

10.00

2.00

2.00

2.00

2.00

2.00

2.00

2.00

2.00

2.00

2.20

2.20

15.00

14.00

15.00

15.00

15.00

15.00

15.00

14.00

16.00

1 1..50

1 1..50

$1.75 \quad 10.00$

6.00

FORGET-ME-NOTS (Myosotis) blue, white or pink

1.00

2.50

1.15

10.00

Cosrula (Blue Plantain Lily)

Subcordata Grand. (Thite Plantain Lily)

Variegata (Blue, yellow banded foliage)

GAILLARDIA

Grandiflora (Blanket Flower, yellow and red).

15.00

GYPSOPHILA

Paniculzta (Baby-sbreath) white.

1.00

6.00

6.00

HELENIUM (Sneczewart)

Autumnale Superbum (Yellow)

Riverton Beauty (Pale Yellow)

Riverton Gem (Old Gold).

HELIOPSIS (Orange Sunflower)

Exrelsa (Yellow)

Piszheriana (Yellow')
1000

40.00

120.00

120.00

120.00

$1: 0.00$

120.00

$1: 0.00$

120.00

120.00

1:0.00

150.00

150.00

50.00 


\section{HARDY PERENNIALS (Continued)}

HEMEROCALLIS (Day Lily)

10

100

1000

Dumortieri (Orange)

$1.00 \quad 6.00$

Lemon Lily (Yellow)

$1.50 \quad 8.00$

Thunbergii (Yellow)

$1.50 \quad 8.00$

HIBISCUS (Meehan's Mallow Marvels)

New Giant, Red, 2 year...

1.50

10.00

60.00

New Giant, Thite, 2 year.

1.50

8.00

50.00

Clumps, heavy mixed colors.

$1 . .0$

8.00

.40 .00

\section{HOLLYHOCKS}

Double Maroon, Pink, Red, Yellow, or White....

1.20

8.00

\section{HYACINTHS}

Candicans (Numerous Thite Bell Flowers)

IBERIS (Candytuft)

Gibraltarica (Gibraltar)

Tencreana (Tenor)

INCOPVILIEA DELAVAYII (Hardy Gloxinia)..........

INULA (Yellow)

$1.00 \quad 6.00$

\section{IRIS, Cerman}

Named varieties as follows:

Afterglow, delicate lavender shading to yellow towards the center.......................................Each 30c

Ambassador, Standards smoky velvety purple, Falls rich carmine purple with yellow beard..Each $\$ 1.00$

Anna Farr, Standards white, delicately bordered with light blue, falls white with blue markings at

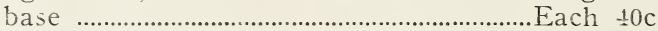

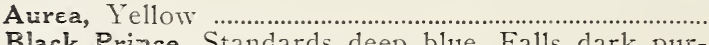

Black Prince, Standards deep blue, Falls dark purple

Bride's Maid, White..........................................................

Celeste, Standards and Falls azure blue............................

Dcrothca, Soft lilac.

Edith, Pink falls white with purple stripes.......................

Fairy Queen, White.

Flavescens, Light Canary Iellow.......................................

Florentiana, Thite

Gertrude, Shades of Blue.

Harlequin, Thite Splashed with Lavender......................

Her Majesty, Fine Pink.

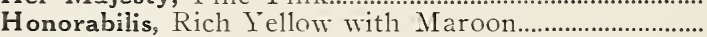

Jeane de Arc, New White.

Lady Stanley, Sulphur Falls Striped IVhite...................

L'Avenier, Standards and Falls Self Color of Delicate Lavender

Lavender, Fine Lavender.

Mde. Cherecin, Standards and Falls White Edged with Light Blue

Mrs. H. Darwin, Standards White, Falls Violet..........

Oriflamme, Rich Violet-Purple. 


\section{HARDY PERENNIALS (Continued)}

IRIS, German (Continued)

10

Purple Kirg

Queen of May (Pink)

Rhein Nixie, Violet Blue with white edge.

Sapho, Violet, Falls, Reddish Blue.

Sherwin Wright, Yellow

Walnerii, Standards Lavender, Falls Deep Lavender

IRIS JAPAN (Kaempferi)

Cekka-No-Nomi, Choicest White, very free.

Iphigenie, Dbl. beautiful coloring deep Chinese Blue Iso-No-Nomi, Rose and Cerulean blue over white....

Kumo-No-Obi, Dark Double Lavender

Melpenone, Double soft blue, veined with dark blue

Patrocole, Reddish Violet.

Purple and Gold, Purple

Reine de Bulgares, Lilac Blie venned with white........

Uchiu, Cerulean Blue.

\section{IRIS}

Siberian, Yale Blue, Strong plants

LATHYRUS (Hardy Sweet Pea)

Latifolius (Mixed)

LILY

Regel, large size $5-\gamma$ in. white, slightly shaded pink..

Tigrinum (Tiger Lily) Orange

LINARIA (Toadflax)

1.00

1.00

1.00

1.00

1.00

100

1000

2.00

17.50

$2.00 \quad 17.50$

$2.00 \quad 17.50$

$2.00 \quad 17.50$

$2.00 \quad 17.50$

$2.00 \quad 17.50$

$2.00 \quad 17.50$

$2.00 \quad 17.50$

$2.00 \quad 17.50$

$1.00 \quad 8.00$

$1.00 \quad 6.00$

$3.50 \quad 30.00$

$1.00 \quad 6.00$

$1.20 \quad 6.00$

LINUM (Flax) Blue or White.

$1.20 \quad 6.00$

\section{LOBELLA}

Cardinalis

$1.75 \quad 15.00$

LUPINUS, Blue or White

$1.50 \quad 8.00$

LYCHNIS (Ragged Robin)

Arkwright

$1.50 \quad 10.00$

$\begin{array}{ll}1.00 & 6.00\end{array}$

Viscaria Splendens

$1.50 \quad 12.00$

\section{LYTHRUM}

Roseum Superbum (Rose Loosestrife)

$1.00 \quad 6.00$

MONARDA (Beebalm)

Cambridge, Scarlet

Didyma, Red

Rosea.

$1.00 \quad 8.00$

$1.00 \quad 8.00$

$1.00 \quad 8.00$

PACHYSANDRA (Japanese Spurge)

Terminalis

PAPAVER (Poppy)

Callirhoe Involuctrata (Red Everblooming Creeping Poppy)

$1.00 \quad 8.00$

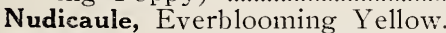

$\begin{array}{rr}1.00 & 8.00 \\ 1.50 & 10.00\end{array}$

Orientale (Oriental Poppy)

$1.00 \quad 8.00$

\section{PENTSTEMON}

Digicalis (Foxglove Pentstemon)...

6.00

Grandiflorus (Shell-leaf Pentstemon)

1.20

6.00

Ovatus (Eggleaf Pentstemon) 


\section{PEONIES}

\section{CHOICE NAMIED VARIETIES}

\section{Standard 3 to 5 Eye Divisions}

Albert Crousse, salmon pink

Each

.50

Alsace Loraine, rich creamy white......................................

Albatre, milk white.

2.00

Augustine d'Hour, large brilliant red.

August Villumns, dark violet rose, globular

Agida, good bright red.

Baroness Schroeder, white shading with flesh.......

Bayadere, large creamy white

Beauty of France, pink

Couronne d'Or, late white....

Chas. Leveque, ball-shaped, salmon rose..............

Canari, white tinted pale pink

Duchess de Nemours, sulphur white

Delact:eii, Red

Delicatissima, Pink

Dr. Brefoneau, pale lilac, flecked with crimson........

Duke of Wellington, white guards, sulphur center....

Edulus Superba, pink.

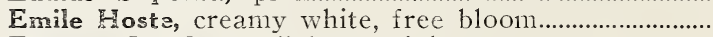

Eugenie Verdier, tall large pirk.........................................

Edouard Andre, dark velvety crimson.

Felix Crousse, red

Fastiva Maxima, white

Fragrance, red

Germaine Bigot, pale lilac rose

Gismonde, lively flesh pink, rose center...........................

Georgiana Shaylor, flesh pink............................................

Glory of Bosicoop, pink.

Golden Harvest, blue and white.

Crover Cleveland, dark crimson.......................................

Humei, clear flesh, tinged rose.........................................

John Hancocks, tall crimson.

Karl Rosenfield, red.

LeFrance, late pink

Laperel, pink

.50

.60

.45

.35

.80

3.50

.35

.35

.40

.35

.35

.40

.35

.35

.35

.30

.80

.45

.60

.50

18.00

3.50

35.00

5.00

30.00

4.00

40.00

3.00

35.00

6.50

25.00

30.00

3.00

60.00

3.00

25.00

3.50

3.00

25.00

30.00

$3.00 \quad 25.00$

$3.50 \quad 28.00$

$3.00 \quad 25.00$

$3.00 \quad 25.00$

$3.00 \quad 25.00$

$2.50 \quad 20.00$

$7.00 \quad 65.00$

$4.00 \quad 35.00$

$5.00 \quad 45.00$

$4.50 \quad 40.00$

$2.50 \quad 22.00$

$3.50 \quad 30.00$

$\begin{array}{lll}.50 & 4.50 \quad 40.00\end{array}$

1.25

10.00

90.00

4.00

35.00

$.40 \quad 3.50$

30.00

$.45 \quad 4.00$

35.00

.70

6.00

55.00

2.50

18.00

6.00

50.00

.75

8.00

65.00

5.00

40.00

3.50

30.00

LaTendresse, white

Livirgston, late pink.

Loxd Kicchener, brilliant cherry red...............................

Louis Van Routeii, red..

La Tulipe, semi-rose type, pink

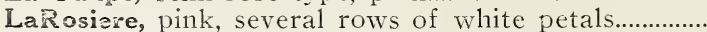

Madame Emile Lemoine, white.

Madame D'Aremberg, brilliant crimson.........................

Madame Emil Galle, soft pink

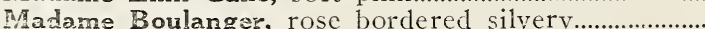

Madame Jules Dessert, white.

Madame Calot, hydrangea pink.......................................

Madame Geissler, rose pink, darker at base.................

Meissonier, dark red.

Mds. De Verneville, white...............................................

Mde. Rousseau, whice touched pink

Marguerite Gerard, pink

Marie Crousse, pink

Marie Jacquin, glossy rosy-white. 
HARDY PERENNIALS (Continued)

PEONIES (Choice Named Varieties) (Continued)

Each

Mary Brand, crimson with silky sheen.

Mons. Jules Elie, pink

15.00

Mons. Krelage, red.

Mons. Martin Cahuzac, maroon

Octavia de May, pink

Officinalis Rubra, early red...................

Pasteur, very soft pink.

5.00

$.50 \quad 4.50$

45.00

2.50

20.00

5.50

40.00

Philipp Rivoire, dark Amaranth-purple.

5.00

1.25

10.00

Perre Ducharter, lilac pink.

President Taft, hydrangea pink.

President Garfield, dark red.....

Primevere, stilphur white, deeper center...........................

President Roosevelt, red........................................................

Quean Victoria, white.

Rackael (Lemoine) fresh pink.

Reine Hortense, pink

Rubra Superba, red.

Rosa Fragrance, light red.

Rubra Triumphuns, red, semi-double

Sarah Bernhardt, late pink.

Solange, amber white.

Solfatare, large yellow.....

Therese, rich satiny pink.

Tourangelle, light pink

Triumphe de Lille, pale hy......................................

Waler $\mathrm{Fax}$, bright

Walker Faxon, bright rose......

Peony, common pink

Peony, common red......

Peony, common white

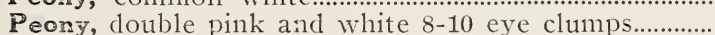
10-1: eye climps.

\subsection{0}

\subsection{5}

10.00

7.50

3.00

50.00

45.00

.35

2.00

18.00

3.50

2.50

5.50

7.50

3.50

2.50

2.50

15.00

1.80

5.00

40.00

$.40 \quad 3.50$

$4.00 \quad 35.00$

$4.00 \quad 35.00$

.45

4.00

4.00

35.00

2.00

2.50

2.50

4.50

6.50

90.00

65.00

25.00

160.00

30.00

20.00

50.00

65.00

30.00

20.00

20.00

120.00

30.00

35.00

15.00

20.00

15.00

40.00

60.00

\section{JAPANESE VARIETIES}

Appleblossom, blush yellow in center filamental petals

Maidens Biush, rose-pink petals with golden center Mikado, dark crimson.

Nishiki Noshotone, blush pink, striped darker pink....

Some Ganoke, rosy crimson petals, center golden lined

Takaradama, single row of pure white petals, golden center

\section{PHLOX}

Aetna, Pink

Antonin Mercie, Grayish Lilac, White Center.

Baron Von Dedum, Pink.

Beacon, Cherry Red.

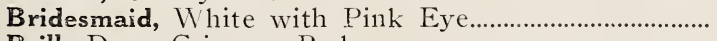

Brill, Deep Crimson Red.

B. Comie, Red.

Champs Elysee, Bright Rose

Commander, Deep Crimson-Red.

Coquelicot, Red

Eclaireur, Red

Elizabeth Campbell, Salmon Pink..................................

Eugene Danzanvilliers, White with Vermilion Eye.... 


\section{HARDY PERENNIALS (Continued)}

PHLOX (Continued)

Europa, Large, White with Red Center....

10

Goliath, Bright Carmine with Red Center.

Grideur, Peach Blosson with Rose Eye.

Henry Murger, White with Deep Rose Center.

Jules Sandeau, Pink.

Lummineaux, Soft Rose.

L'Evenement, Tender Salmon Pink.

Mde. P. Deutrie, Orchid Pink.

Millie Von Hoboken, Pink.

Miss Lingard, IThite..

Mrs. Chas. Dorr, Solid Blue-Mauve.

Mrs. Jenkins, White.

Pantheon, Pink

Prof. Virchow, Bright Carmine.

Rheinlander, Salmon Pink.

Riverton Jewell, Pink

R. P. Siruthers, Carmine...

Rosenberg, Reddish Violet.

Rynstrom, Rose Pink.

Siebcldi, Red

Special French, New Salmon Pink.

Sunset, Pink

Thor, Salmon Pink

Viking, Soft Rose.

Von Hockbarg, Red

Von Lassburg, White.

1.50

100

1000

1.50

10.00

75.00

10.00

75.00

$\begin{array}{lll}1.50 & 10.00 & 75.00\end{array}$

$1.50 \quad 10.00 \quad 75.00$

$1.50 \quad 10.60 \quad 75.00$

$\begin{array}{lll}1.50 & 10.00 & 75.00\end{array}$

$\begin{array}{lll}1.50 & 10.00 & 75.00\end{array}$

$1.50 \quad 10 . C \% \quad \% 5.00$

$1.50 \quad 10.00 \quad 75.00$

$\begin{array}{lll}1.50 & 10.00 \quad \% 5.00\end{array}$

$\begin{array}{lll}1.50 & 10.00 \quad 75.00\end{array}$

$\begin{array}{lll}1.50 & 8.00 \quad 50.00\end{array}$

$1.50 \quad 10.00 \quad 75.00$

$\begin{array}{lll}1.75 & 12.00 & 100.00\end{array}$

$\begin{array}{lll}1.50 & 10.00 & 75.00\end{array}$

$\begin{array}{lll}1.50 & 10.00 & 75.00\end{array}$

$\begin{array}{lll}1.50 & 10 . \mathrm{C0} & 75.00\end{array}$

$1.50 \quad 10.00 \quad 75.00$

$\begin{array}{lll}1.50 & 10.00 & 75.00\end{array}$

$\begin{array}{lll}1.50 & 10.00 \quad 75.00\end{array}$

$2.00 \quad 15.00$

$1.50 \quad 10.00$

$1.75 \quad 12.00$

75.00

100.00

$\begin{array}{lll}1.50 & 10.00 & 75.00\end{array}$

$\begin{array}{lll}1.50 & 10.00 & \% 5.00\end{array}$

$\begin{array}{lll}1.50 & 8.00 \quad 50.00\end{array}$

PHYSOLIS (Japanese Lantern)

Francheti

1.00

6.00

PLATYCODON (Chinese Beil Flower)

Grandiflora, Blue

Grandiflora, White

Mixed Colors

PLUMBAGO

Blus, All Summer

PYRETHRUM

Grandiflorum, Mixed Colors.

Roseum, Painted Daisy

Ulignosa Stellata, White with brown eye.

RANUNCLUS (Double Buttercup)

Acris, Tall Yellow..

RUDEBECKIA

Golden Glow, Yellow.

Newmanii

Purpurea (Cone Flower)

SALVIA (Sage)

Argencia (Silver Salvia)......

Protensis (Meadow Sage)

$1.00 \quad 6.00$

$1.00 \quad 6.00$

$1.00 \quad 5.00$

1. $\% 5 \quad 12.00$

1.00

1.00

7.00

12.00

$1.50 \quad 10.00$

$1.00 \quad 7.00$

$1.00 \quad 8.00$
1.50

$1.50 \quad 10.00$

$1.00 \quad 6.00$

$1.00 \quad 6.00$

SCABIOSA (Blue Bonnet)

Alba, White

Caucasica (Blue Pin Cushion Flower).............................

Japoniza, Lavender

$\begin{array}{rr}1.00 & 6.00\end{array}$

$1.20 \quad 10.00$

$1.00 \quad 6.00$

SEDUM (Stonecrop)

Acre, Yellow

$\begin{array}{ll}1.50 & 10.00\end{array}$

Brilliant

1.50

10.00

Kamtschoticum (Orange Sedum)

$2.00 \quad 1 \% .50$

Spectabilis (Showy Sedum) Pink......

$1.50 \quad 10.00$

Spurium Coccinium

$1.00 \quad 8.00$ 


\section{HARDY PERENNIALS (Continued)}

SOLIDAGO (Goldenrod)

$10 \quad 100 \quad 1000$

Canadensis, Yellow

$1.00 \quad 5.00$

STATICE (Thrift)

Latifolia (Sea Lavender) I_avender Blue...................... $1.00 \quad 6.00$

Tartarica, IThite ................................................................... $1.00 \quad 6.00$

TRITOMA

Grandiflora

$1.00 \quad 6.00$

Pf: $z$ zrii

$1.75 \quad 15.00$

VERONICA (Speedwell)

Ameilystina (Boston Speedwell) Blue........................ $1.00 \quad 0.00$

Incana, Decp Blue Flowers. Silvery Foliage.................... 1.i. 12.00

Longifo!ia Subsessilis, Blue................................................. $1.50 \quad 10.00$

Spicata (Spike Veronica) Tiolet Blue Flowers.......... $1.00 \quad 6.00$

YUCCA

Filimentosa (Common Yucca) White, 2 yr.................. $1.00 \quad 6.00$

Variegata, New Variegated Leaf́....................................... $5.00 \quad 40.00$

\section{HYACINTHS}

L'Innocence, LaGrandesse, Quesn of the Whites, Argentine Arendsen, Gertruds, Lady Derby, LaVictoire, Queen of the Pinks, Bismarck, Grand Maitre, King of the Blues, Perle Brilliant, Yellow Hammer, City of Haarlem and Mixed.

100 per bag: do not break bags

Per 1000

Exhibition Size, 19 ctms. and up........................................................................ 143.00

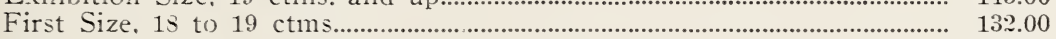

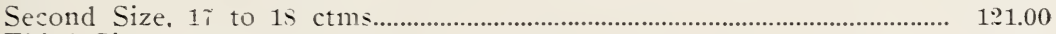

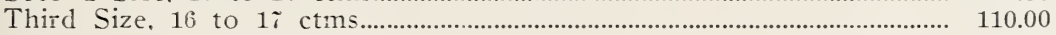

Forcing Size, 15 to 16 ctms............................................................................. 99.00

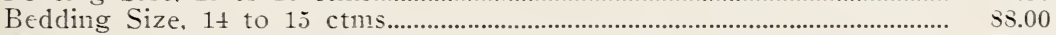

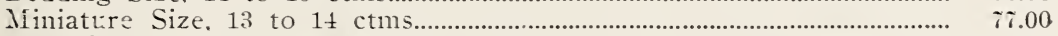

NOTE-Tulips and Miscellaneous bulbs 250 per bag: unless otherwise noted, do not break bags.

\section{SINGLE EARLY TULIPS}

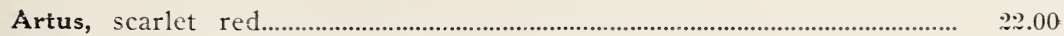

Brilliant Star, cardinal red forcer..................................................................... $\quad 44.00$

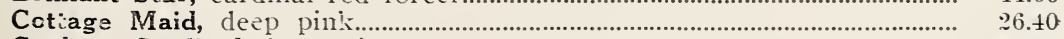

Couleur Cardinal, late crimson.......................................................................... $\quad 44.00$

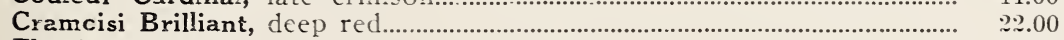

Flamingo, deep rose pink .................................................................................... 33.00

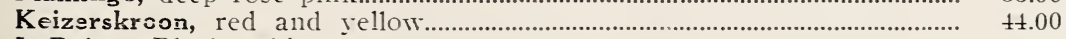

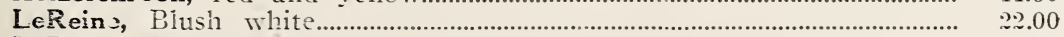

LaReize, Maxima, light pink

Mo:Trssor, large yellow, eary -orcer........................................................... 44.00

Prince of Ausiria, orange red.......................................................................... $\quad 44.00$

Prosperity, deep pink, early............................................................................... 33.00

Rese Grislian, light pink.................................................................................. $\quad 26.40$

Rose Luisante, bright rose forcer........................................................................ $\quad 4.00$

Rose LaReine, light pink..................................................................................... 33.00

Vermillion Brilliant, Vermillion trf................................................................... $\quad \$ 4.00$

Whice Hawk, pure white, early forcer............................................................. $\quad 33.00$

Yellow Prince, pure vellow forcer............................................................................ 33.00

Choice Mixiure ................................................................................................ 1 1 .60 


\section{DOUBLE EARLY TULIPS}

Per 1000

Boule de Neige, pure white 33.00

Couronne d'Or, orange yellov

ElToreador, red and orange.

LeMalador, scarlet

39.60

Lucretia, scarlet forcer.

33.00

Murillo, light pink forcer.

26.40

Peachblossom, deep pink forcer..

55.00

Rubra Maxima, deep red.

Salvator Rosa, deep rose

Schoonoord, pure white

Tea Rose, sulphur yellow.

Titian, red and yellow.

Tournesol, red and yellow.

Vurrbaak, scarlet forcer.

Choice Mixture

\section{DARWIN TULIPS}

Baronne de la Tonnaye, bright rose.

Bartigon, brilliant red, early.

Bleu Aimable, light blue.

Clara Bute, salmon pink

Crepuscle, pure lilac.

Centenaire, large early pink.

Dream, deep lilac.

Farcombe Sadaders, bright scarlet.

Feu Brillant, fiery scarlet.

Gretchen, soft pink.

Homer, earliest scarlet forcer

La Tulipe Noire, the black tulip.

LeNotre, earliest rose pink.

Mme. Krelage, rose pink.

Mrs. Potter Palmer, deep puiple

Nauticus, purple rose.

Painted Lady, light rose.

Phillip de Comines, maroon black.

22.00

22.00

Pride of Haarlem, American beauty color.................................................... 17.60

Princess Elizabeth, vivid pink......................................................................... 33.00

Prof. Rauwenhoff, light red........................................................................... $\quad 26.40$

Psyche, pretty light rose.....

Rev. Ewbank, light heliotrope.

Sieraad van Flora, dark rose pink ..................................................................... 22.00

The Sultan, brown black.

White Queen, large white.

Wm. Copeland, lavender, earliest forcer.......................................................... 22.00

Wm. Pitt, brilliant scarlet................................................................................ 33.00

Choice Mixture 


\section{SINGLE LATE OR COTTAGE TULIPS}

Beuton d'Or, golden yellow.

Carnation, salmon red...

Ellen Willmott, soft yellow.

Gesneriana Spathulata, red.

Golden Crown, yellow red edge........................................................................ 22.00

Inglescombe, yellow ........................................................................................ 22.00

Inglescombe, scarlet …...................................................................................... 22.00

Inglescombe, pink ......................................................................................... 22.00

Isabella, rosy white......................................................................................... 22.00

Parisian White ............................................................................................. 22.00

Parisian Yellow ....................................................................................................... 22.00

Parisian Scarlet ................................................................................................. 22.00

Picotee (Maiden's Blush) white pink edge................................................... 22.00

The Fawn, frayish rose.................................................................................. 22.00

Choice Mixture

\section{BREEDER TULIPS}

Alcida, yellow and bronze.

Aspasia, purple red.

Bronze King, brown and red.

Cardinal Manning, rosy violet sailmon.

Chestnut, purple maroon..

General Ney, olive bronze

Golden Bronze, beautiful bronze........................................................................ $\quad 33.00$

Godet Parfait, bright purple violet................................................................... 55.00

Jaune d'Oeuf, salmon bronze.................................................................................. $\quad 33.00$

Klopstock, finest blue.

LeMogul, light blue, silvery base..................................................................... 33.00

Madras, dark bronze yeliow............................................................................ 27.50

Medea, salmen violet......................................................................................... $\quad 27.50$

Noir Veritable, almost black.............................................................................. 33.00

Prince of Orange, golden orange...................................................................... $\quad 47.50$

Rose des Dames, rosy lilac.............................................................................. $\quad 27.50$

Velvet King, largest violet.................................................................................... 66.00

Yellow Perfection, best yellow bronze............................................................... 44.00

Choice Mixture ................................................................................................... $\quad 27.50$

\section{MISCELLANEOUS BULBS}

Anemone the Caen

Baby Gladiolus, Peach Blossom, Blushing Bride......................................... 27.50

Chionodoxa Luciliae ......................................................................................... $\quad 22.00$

Colchicum Autummalis (100 per bag).............................................................. 165.00

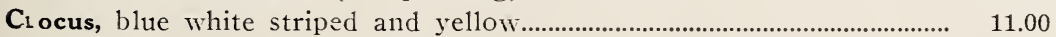

Crown Imperial (100 per bag) ......................................................................... 165.00

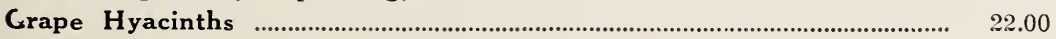


Iris Filifolia Imperator

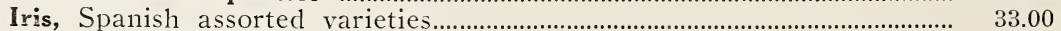

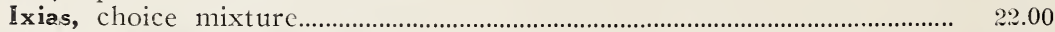

Ornithogalum Umbellatum …..................................................................... 22.00

Oxalis

Ranunculus, French Mixture

27.50

27.50

Scilla Sibirica

Snowdrops

Winter Aconite

\section{FREESIA PURITY}

$1 \frac{1}{4}$ to $13 / 4$ inch

$13 / 4$ to 2 inch.

2 inch and up

\section{CALLA AETHIOPICA}

$1 \mathrm{I} / 2$ to $13 / 4$ inch (100 per bag).

\section{LILIUM CANDIDUM}

20 to 22 ctms. (100 per bag)

LILIUM ERABU

7 to 9 inches, 300 to case

Per Case

8 to 10 inches, 225 to case

9 to 10 inches, 200 to case.

\section{LILIUM FORMOSUM}

7 to 9 inches, 300 to case

\section{DAFFODILS}

\section{Hardy American Grown, 100 per bag}

\begin{tabular}{|c|c|}
\hline Emperor & 67.00 \\
\hline & 78.00 \\
\hline den Spur & 77.00 \\
\hline mparalles & 55.00 \\
\hline 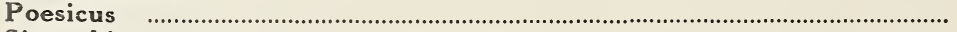 & 44.00 \\
\hline askin & 77.00 \\
\hline & 78.00 \\
\hline Eellanecus Narcissus & 33.00 \\
\hline
\end{tabular}




\section{LINING OUT STOCK \\ EVERGREENS \\ NOTE: C Represents Rooted Cuttings \\ $S$ Represents Seedilings \\ T Represents Transplants \\ TT Represents Twice Transplanted}

Evergreens rooted cuttings and seedlings are suitable only for bedding out. Transplanted evergreens are suitable to line direct to the field.

\section{ABIES (Fir)}

Balsamea (Balsam Fir)

2 to 4 inch $\mathrm{T}$

Concclor (Concolor Fir)

\pm to 6 inch $\mathrm{S}$.

$6.00 \quad 50.00$

6 to $S$ inch $\mathrm{TT}$

$31.00 \quad 255.00$

Fraseri (Fraser Fir)

2 to \pm inch $\mathrm{I}$.

$6.00 \quad 45.00$

\pm to 6 inch $\mathrm{T}$

\%.00 60.00

Homolepsis (Nikko Fir)

4 to 6 inch 2 year $\mathrm{S}$

\%.00 55.00

2 to 4 inch $\mathrm{T}$

1 to 6 inch $\mathrm{T}$

$11.00 \quad 95.00$

Veitchii (Veitch Fir)

4 to 6 inch $\mathrm{T}$

$9.00 \quad 75.00$

BIOTA

Orientalis Aurea Nana (Berkman Golden Arborvitae) 4 to 6 inch $\mathrm{T}$.

6 to 8 inch $\mathrm{T}$

Orientalis Bonita \pm to 6 inch $T$

$14.00 \quad 125.00$ 6 to 8 inch $\mathrm{T}$

$17.50 \quad 150.00$

Orientalis Compacta

4 to 6 inch $\mathrm{T}$

$14.00 \quad 125.00$

6 to 8 inch $\mathrm{T}$

$20.00 \quad 150.00$

Orientalis Pyramidalis (Oriental Pyramidal Arborvitae)

4 to 6 inch $\mathrm{T}$

6 to 8 inch $\mathrm{T}$

$14.00 \quad 125.00$

$17.50 \quad 150.00$

Orientalis Pyramidalis (Baker's)

6 to 8 inch T.

$20.00 \quad 150.00$

\section{JUNIPER}

\section{Cannartii}

No. 1 Grafted.

\section{Chinensis}

$$
2 \text { to } 4 \text { inch S. }
$$

Chinensis Pfitzeriana (Pfitzer Juniper)

4 to 6 inch $\mathrm{T}$.

8 to 10 inch TT

Communis (Common Juniper)

$$
6 \text { to } 8 \text { inch } \mathrm{S} \text {. }
$$

8 to 10 inch S.

Communis Depressa (Prostrate Juniper)

6 to 8 inch S. 


\section{LINING OUT STOCK (Continued)-Evergreens}

JUNIPER (Continued)

Communis Hibernica (Irish Juniper)

6 to 8 inch $\mathrm{T}$.

100

1000

8 to 10 inch $T$.

8.00

75.00

$1+. \mathrm{U} \quad 100.00$

Excelsa Stricta (Spiny Greek Juniper)

8 to 10 inch TT

35.00

Horizontalis Douglasi (Waukegan Juniper)

6 to $\mathrm{S}$ inch $\mathrm{T}$.

25.00

200.00

Sabina (Savin Juniper)

4 to 6 inch $\mathrm{T}$.

8 to 10 inch TT

10 to 12 inch TT

17.50

150.00

$36.00 \quad 305.00$

$51.00 \quad 455.00$

\section{Schotti}

No. 1 Grafted.

45.00

Medium Grafted

Scopolurum (Colorado Juniper)

4 to 6 inch $\mathrm{S}$

6 to 8 inch S

40.00

$7.00 \quad 55.00$

$9.00 \quad 75.00$

Virginiana (Red Cedar)

6 to 8 inch S

$8.00 \quad 65.00$

6 to 8 inch $\mathrm{T}$.

$8.50 \quad 75.00$

8 to 12 inch $\mathrm{T}$

12.00

100.00

Virginiane, Glauca

No. 1 Grafted.

45.00

Medium Grafted

40.00

PICEA (Spruce)

Canadensis (White Spruce)

4 to 6 inch S.

6 to 8 inch $\mathrm{S}$.

8 to 10 incil $T$.

10 to 12 inch TT

12 to 18 inch TT

Canadensis Albertiana (Black Hill Spruce)

4 to 6 inch S.

4 to 6 inch $\mathrm{T}$.

Excelsa (Norway Spruce)

4 to 6 inch $\mathrm{S}$

6 to 8 inch $\mathrm{S}$

6 to 8 incl $\mathrm{T}$.

8 to 10 inch $\mathrm{T}$.

8 to 10 inch TT

10 to 12 inch TT

5.00

35.00

$\begin{array}{ll}5.50 & 40.00\end{array}$

$12.00 \quad 100.00$

$25.00 \quad 225.00$

$35.00 \quad 300.00$

$\begin{array}{ll}5.50 & 40.00\end{array}$

$7.00 \quad 55.00$

$3.50 \quad 20.00$

$4.00 \quad 22.50$

$9.00 \quad 75.00$

$12.00 \quad 100.00$

$15.00 \quad 115.00$

$\begin{array}{ll}17.50 & 150.00\end{array}$

Pungens (Colorado Blue)

4 to 6 inch S

6 to 8 inch $\mathrm{S}$................

6 to 8 inch ' $T$

8 to 10 inch $\mathrm{T}$

10 to 12 inch $\mathrm{T}$

$5.50 \quad 40.00$

$6.50 \quad 50.00$

$16.00 \quad 145.00$

$20.00 \quad 170.00$

$25.00 \quad 200.00$

PINUS (Pine)

Montana (Swiss Mountain)

2 to $t$ inch 2 year $S$.

4 to 6 inch 3 year $\mathrm{T}$.

6 to 8 inch 4 year $\mathrm{T}$.

Mugho

2 to 4 inch $\mathrm{T}$

4 to 6 inch $\mathrm{TT}$

6 to 8 inch 6 year TT 


\section{LINING OUT STOCK (Continued)-Evergreens}

PINUS (Pine) (Continued)

100

1000

Nigra (Austrian Pine)

4 to 6 inch 2 year $\mathrm{S}$...

35.00

6 to 8 inch $\mathrm{T}$

9.50

8 to 10 inch $\mathrm{T}$.

12.00

80.00

10 to 12 inch TT.

$15.00 \quad 125.00$

Ponderosa Scopulorum (Ponderosa Pine)

4 to 6 inch 2 year 5

$4.00 \quad 25.00$

Resinosa (Red)

4 to 6 inch 2 year $\mathrm{S}$

6 to 8 inch 3 year $\mathrm{T}$.

$7.00 \quad 60.00$

$10.00 \quad 90.00$

Strobus (White Pine)

6 to 8 inch $\mathrm{T}$

$9.00 \quad 75.00$

8 to 10 inch $\mathrm{T}$.

$12.00 \quad 100.00$

Sylvestris (Scotch Pine)

4 to 6 inch 2 year $S$

6 to 8 inch $\mathrm{T}$.

8 to 10 inch $\mathrm{T}$

$3.50 \quad 20.00$

$8.00 \quad \% 0.00$

$10.00 \quad 80.00$

\section{PSEUDOTSUGA}

Douglasi (Douglas Fir)

4 to 6 inch $S$

10 to 12 inch TT

\section{RETINOSPORA}

\section{Pisifera}

4 to 6 inch $\mathrm{C}$

10.00

75.00

Plumosa

4 to 6 inch $\mathrm{C}$

20.00

12.00

95.00

7 to 9 inch $\mathrm{T}$

17.50

Plumosa Aurea

4 to 6 inch $C$

1:. 00

20.00

Squarrose

$\gamma$ to 9 inch $\mathrm{T}$

4 to 6 inch $\mathrm{C}$

9.00

20.00

TAXUS

Canadensis (American Yew)

8 to 10 inch $\mathrm{T}$

15.00

THUJA (Arborvitae)

Occidentalis (American Arborvitae)

4 to 8 inch $\mathrm{S}$

$(\$ 12.00 \mathrm{M}$ in $5 \mathrm{M}$ lots)

8 to 12 inch $\mathrm{S}$

$(\$ 17.50 \mathrm{M}$ in $5 \mathrm{M}$ lots)

12 to 18 inch $\mathrm{S}$

8 to 10 inch TT.

10 to 12 inch TT.

12 to 18 inch TT.

Occidentalis Globosa (Globe Arborvitae)

4 to 6 inch $\mathrm{T}$

6 to 8 inchTT

Occidentalis Hoveyi (Hovey Arborvitae)

4 to 6 inch $\mathrm{T}$.

10 to 12 inch TT.

Occidentalis Pyramidalis (Pyramidal Arborvitae)

4 to 6 inch $T$

8 to 10 inch $\mathrm{TT}$

2.0

15.00

3.00

20.00

5.50

35.00

8.50

₹0.00

$10.00 \quad 85.00$

$20.00 \quad 190.00$

$12.00 \quad 95.00$

$15.00 \quad 140.00$

$12.00 \quad 95.00$

$22.50 \quad 200.00$

$11.00 \quad 95.00$

$17.50 \quad 150.00$

10 to 12 inch $\mathrm{TT}$

$22.50 \quad 200.00$ 


\section{LINING OUT STOCK (Continued)-Evergreens}

THUJA (Arborvitae) (Continued)

Osciden:alis Tom Thumb (Tcm Thumb Arborvitae)

4 to 6 inch $\mathrm{C}$

5 to 7 inch $T$

$i$ to 9 inch $\mathrm{T}$

Occidentalis Wareana (Ware Arborvitae)

6 to 10 inch $\mathrm{T}$

Ozcidentalis Wcodwardi (Woodward Arborvitae)

8 to 10 inch $T$ T

10 to $1:$ inch TT

TSUGA (Hemlock)

Canadensis

$\frac{1}{t}$ to 5 inch TT

$100 \quad 1000$

6 to 8 inch TT

$10.00 \quad 60.00$

$15.00 \quad 120.00$

$20.00 \quad 150.00$

$25.00 \quad 200.00$

35.00

45.00

13.50

120.00

$16.50 \quad 150.00$

\section{FRUIT AND URDERSTOCK}

\section{APPLE SEEDLINGS}

No. $11 \frac{1}{4}$ inch and up straight..

14.00

(\$11.00 M in 25M lots)

3-16 inch and up straight.

(\$10.00 $\mathrm{M}$ in $25 \mathrm{M}$ lots)

No. $22^{1 / 2-16}$ to $3^{1 / 2-16}$ straight branched.

Special Grade, 3-16 inch and up stort roots suitable for budding or grafting.

MAHALEB, French Grown

3 to $5 \mathrm{mml} 1$ year.

5 to 9 mm 1 year

12.00

8.00

6.00

10.00

15.00

ROSA MULTIFLORA JAPONICA

3 to $t \mathrm{~mm}$

In : M Lots

In 5 M Lots.

In 10 M Lots.

In $20 \mathrm{M}$ Lots.

In $25 \mathrm{M}$ Lots....

$\therefore$ to $3 \mathrm{~mm}$

In 50 M Lots.

In $2 \mathrm{M}$ Lots

In 5 M Lots.

In $10 \mathrm{M}$ Lots.

In 20 M Lots.

In 25 M Lots.

In $50 \mathrm{M}$ Lots.

15.00

14.00

13.00

12.50

12.00

11.50

11.00

9.00

8.50

8.00

7.50

7.00

6.50

6.00

\section{SHADE TREES}

AESCULUS (Horsechestnut)

Hippocastanum (Horsechestinut)

10 to 15 inch.

Ostrandra (Yellow Buckeye)

$t$ to 6 inch Seedlings

6 to 12 inch Seedlings

4.00

35.00

12 to 18 inch Seedlings

\section{AILANTHUS}

Glandulcsa (Tree of Heaven)

12 to 18 inch.

18 to $2 t$ inch 


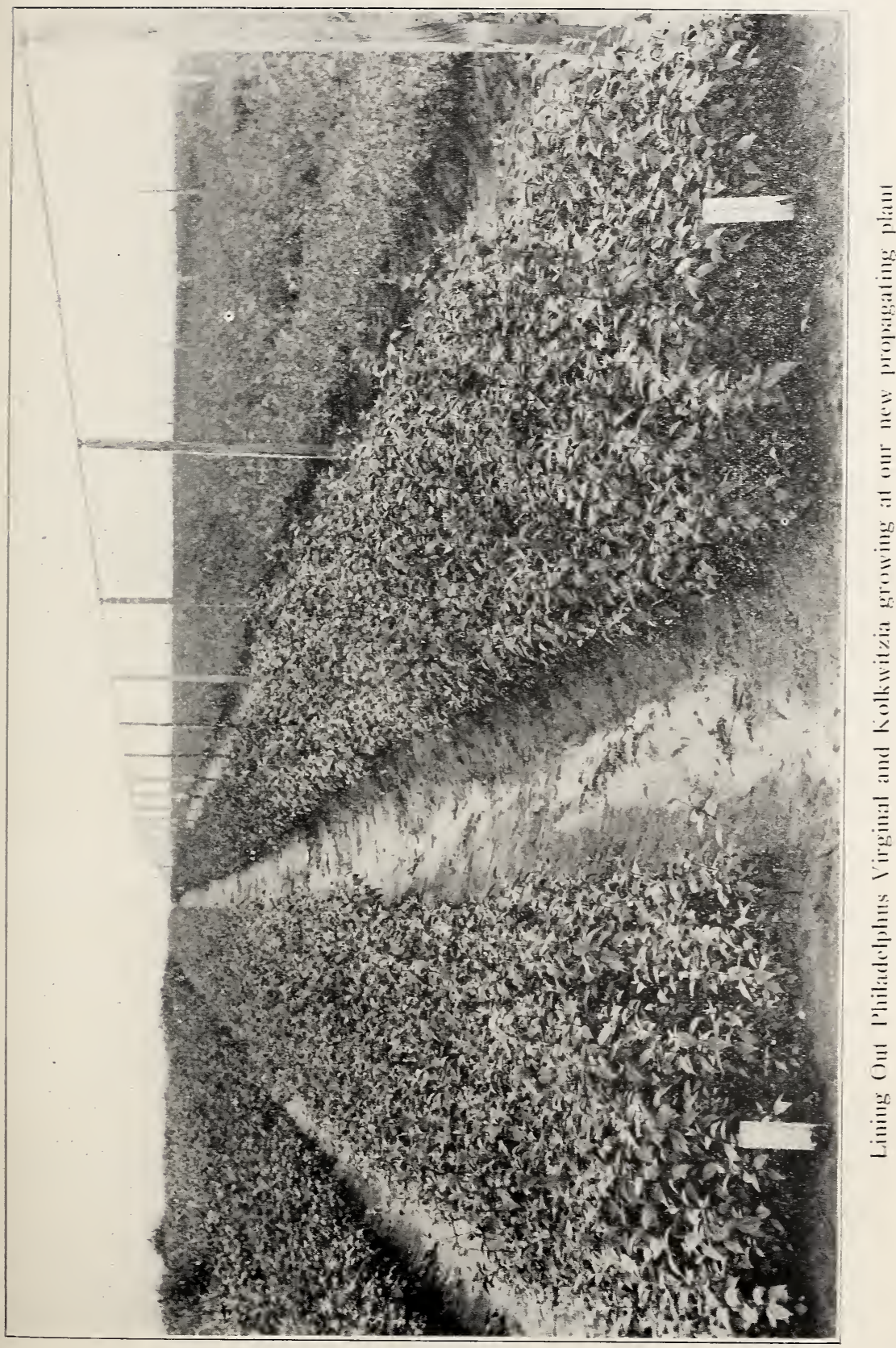




\section{LINING OUT STOCK (Continued)-Shade Trees}

ALNUS (Alder)

Speckled Alder (Incana)

18 to 24 inch 2 year...

100

1000

ANDROMEDIA (Bog Rosemary)

6 to 12 inch Seedlings

30.00

12 to 18 inch Seedlings

ASH (Fraxinus)

European Mountain 12 to 15 inch Seedlings

Green

White

18 to 24 inch

2.00

15.00

BIRCH (Betula)

Canoe Birch (Papyrifera)

12 to 24 inch 2 year.

European White Birch (Alba)

6 to 9 inch 2 vear.

6.50

60.00

Grey Birch (Populifolia)

12 to 24 inch 2 year

River Birch (Nigra)

6 to 12 inch Seedlings

1.20

10.00

12 to 18 inch Seedlings

1.35

12.50

18 to 24 inch Seedlings

1.75

15.00

Sweet Birch (Lenta)

12 to 24 inch 1 year

Yellow Birch (Lutea)

12 to 24 inch 2 year

$4.00 \quad 35.00$

$4.50 \quad 40.00$

BLACK GUM (Nyssa Multiflora)

6 to 12 inch

12 to 18 inch

$2.00 \quad 15.00$

BOX ELDER (Acer Negundo)

6 to 12 inch.

12 to 18 inch

18 to 24 inch

$.75 \quad 4.00$

$1.00 \quad 6.00$

$1.50 \quad 9.00$

CARPINUS AIMERICANA (Water Beech)

6 to 12 inch Seedlings

12 to 18 inch Seedilings

1.150

$2.50 \quad 20.00$

CASTAPEA DENTATA (American Sweet Chestnut)

6 to 12 inch Seedlings.

12 to 18 inch Seedlings

$5.50 \quad 45.00$

$7.50 \quad 65.00$

CATALPA SPECIOSA

6 to 12 inch Seedlings

12 to 18 inch Seedlings

1.50

6.00

18 to 24 inch

2 to 3 feet.

2.00

8.00

2.50

17.50

CELTIS (Hackberry)

Occidentalis (Hackberry)

9 to 12 inch 1 year

12 to 15 inch 1 year.

Coccinea (Thicket Hawthorne) 10 to 15 inch 2 year...

Oxyacantha (English Hawthorne) 6 to 8 inch.

Tomentosa (Pear Hawthorne) Lining Out 


\section{LINING OUT STOCK (Continued)-Shade Trees}

ELM (Ulmus)

Ameri an White

12 to 15 inch Seedlings

18 to 24 inch Seedlings.

2 to 3 feet Seedlings.

100

1000

\section{Chinese}

$\begin{array}{rr}2.00 & 12.00 \\ 2.50 & 15.00 \\ 3.00 & 20.00 \\ & \\ 6.00 & 55.00 \\ 7.00 & 55.00 \\ 1.2 .50 & 100.00 \\ & \\ 4.50 & 40.00 \\ 5.50 & 5000 \\ 6.50 & 50.00 \\ 7.50 & 70.00\end{array}$

FAGUS (Beech)

12. to 18 inch Seedlings heary

15 to $2+$ inch Seedlings heary

2 to 3 feet Seedlings heary...

Chirese, Lighter grade Seedlings

9 to 12 inch.

12 to 15 inch.

18 to 24 inch.

2 to 3 feet.

American Beech (Americana)

12 to 18 inch 2 year.

GINKGO (Maiden-Hair Tree)

Maiden-Hair Tree (Biloba)

6 to 10 inch 1 year..

\section{GYMNOCLADUS}

Kentusky Coffestree (Dioica)

6 to 12 inch 1 year..

12 to 18 inch 1 year.

$5.50 \quad 50.00$

HICOßIA (Hickory)

Shell Bark Hickory (Laciniosa)

6 to 12 inch Seedlings.

Shag Bark Hickory (Orata)

6 to 12 inch Seedlings.

LINDEN (Tilia)

Parvifolia (European Linden)

6 to $\mathrm{S}$ inch.

12 to 18 inch.

Vulgaris (European Red Twig Linden) 10 to 15 inch.

\section{LIQUIDAMBAR}

Sweet Gum (Styraciflua) 12 to 18 inch 1 yеar..

LOCUST (Robinia)

Black Pseudoacacia)

6 to 12 inch

12 to 18 inch.

18 to 24 inch.

2 to 3 feet

Honey (Gleditsia)

12 to 18 inch.

MAPLE (Acer)

Norway (Platanoides)

$t$ to 5 feet whips.

5 to 6 feet whips

6 to $r$ feet whips

7 to 8 feet whips

Silver (Dasycarpum)

6 to 12 inch Seedlings

12 to 18 inct Seedlings 


\section{LINING OUT STOCK (Continued)-Shade Trees}

MAPLE (Acer) Continued)
Sugar

6 to 12 inch Seedlings.

100

1000

12 to 18 inch 2 year Seedlings

$2.00 \quad 15.00$

18 to 24 inch 2 year Seedlings.

$3.00 \quad 25.00$

MELIA

Texas Umbrella Tree (Umbraculiformis)

6 to 12 inch Seedlings....

12 to 18 inch Seedlings.

18 to 24 inch Secdlings.

$4.00 \quad 35.00$

MULBERRY (Morus)

\section{Russian}

6 to 12 inch

12 to 18 inch

18 to 24 inch

PERSIMMON (Diospyros)

American (Virginiana)

12 to 18 inch.

18 to 24 inch

2 to 3 feet.

PLATANUS (Planetree)

American Planetree (Occidentalis)

12 to 18 inch 1 year..

12 to 24 inch 1 year.

POPLAR (Populus)

Balm of Gilead (Candicans)

12 to 18 inch.

18 to 24 inch..

2 to 3 feet.

Carolina and Norway

18 to 24 inch..

2 to 3 feet.

3 to 4 feet

Lombardy and Volga

18 to 24 inch.

2 to 3 feet.

3 to 4 feet.

Silver Leaf

12 to 18 inch (C) Whips.

18 to 24 inch (C) Whips

2 to 3 feet (C) Whips.

Simond's Pyramidal

12 to 18 inch.

18 to 24 inch.

2 to 3 feet.

3 to 4 feet

QUERCUS (Oak)

Northern Red Oak (Rubra Ambigua)

4 to 8 inch 1 year..

8 to 12 inch 1 rear.

$2.00 \quad 15.00$

$2.50 \quad 20.00$

$3.00 \quad 25.00$

$2.50 \quad 20.00$

$3.50 \quad 25.00$

$4.50 \quad 35.00$

$2.50 \quad 20.00$

$3.00 \quad 25.00$

$5.00 \quad 35.00$

$\begin{array}{ll}3.00 & 25.00\end{array}$

$3.50 \quad 30.00$

$4.50 \quad 40.00$

$2.00 \quad 15.00$

$3.00 \quad 20.00$

$3.50 \quad 25.00$

$5.00 \quad 35.00$

$3.00 \quad 25.00$

$4.00 \quad 35.00$

Pin Oak (Pulastris)

8 to 12 inch 1 year..

$5.50 \quad 50.00$

$3.50 \quad 30.00$

SASSAFRASS

4 to 6 inch 1 year.

Varifolium (Common Sassafrass)

12 to 18 inch. 


\section{LINING OUT STOCK (Continued)-Shade Trees}

SYCAMORE, American

100

1000

12 to 18 inch

$3.00 \quad 22.50$

18 to 24 inch

TULIPTREE (Liriodendron)

Tulipifera

12 to 18 inch Seedlings.

18 to 24 inch Seedlings

WALNUT (Juglans)

Cinerea (White Walnut) Butternut

6 to 12 inch Seedlings.........

12 to 18 inch Seedlings.

18 to 24 inch Seedlirigs.

Nigra (Black Walnut)

6 to 12 inch Seerlings.

12 to 18 inch Seedlings

18 to 24 inch Seecilings.

WILLOW (Salix)

Alba Niobe (Weeping Willow)

2 to 3 feet 1 year..

3 to 4 feet 1 year.

Babylonica dolorosa (Wisconsin Weeping Willow)

2 to 3 feet 1 year...

3 to 4 feet 1 year..

Basket-Used for tying bundles of nursery stock

12 to 18 inch 1 year C.

18 to 24 inch 1 year C

2 to 3 feet 1 year C..

Caprea (Pussy Willow)

6 to 12 inch 1 year $C$

12 to 18 inch 1 year $C$

2 to 3 fect 1 year $\mathrm{C}$

Pentandra (Laurel Willow)

2 to 3 feet 1 year.

Viminalis (Common Willow)

12 to 18 inch 1 year C.......

Vitellina Aurea (Russian Golden Willow)

2 to 3 fect 1 year.

WITCH HAZEL (Hamamelis)

Virginiana (Common Witch Hazel)

12 to 18 inch. 


\section{LINING OUT STOCK SHRUBS, VINES AND CREEPERS}

ALTHEA, Seedlings

6 to $1:$ inch

12 to 18 inch

18 to 24 inch

2 to 3 feet..

$3.00 \quad 14.00$

Named varieties from cuttings

6 to 12 inch

12 to 18 inch

$3.75 \quad 27.50$

18 to 24 inch

$4.50 \quad 35.00$

Amplissima, double rosy red

Ardens, purple

Bicolor, double white with red eye

Boule de Feu, double red

Duchess de Brabant

Comte de Haimont, pink

Elegantissima

Jeanne de Arc, double white

Lady Stanley, white shaded rose

$P_{2, \bullet}$ oniflora, white with cherry red center

Pulcherimus, variegated flower

Totus Alba, single white

AMELANCHIER (Junebcrry)

12 to 15 inch

AMORPHA (False Indigo)

Fruticosa (Indigo bush)

6 to 12 inch....

12 to 18 inch

AMPELOPSIS

Engelmanii (Engelman Crecper)

1 year No. 1

Quirquefolia (Virginia Creeper)

1 year No. 1.

Veitchii (Boston Ivy)

1 year No. 1

ARALIA PENTAPHYLLA

6 to 12 inch.

18 to 24 inch

AROPJA (Chokeberry)

Arbutifolia (Red)

18 to 24 inch.

\section{AZALEA}

Mollis

Seedlings

BARBERRY (Berberis)

Thunbergii (Japanese)

6 to 9 inch seedlings

9 to 12 inch seedlings

12 to 15 inch seedlings

Atropurpurea (Red Leaf Barberry)

6 to 8 inch 1 year. 


\section{LINING OUT STOCK \\ SHRUBS, VINES AND CREEPERS (Continued)}

BIGNONIA (Trumpet Creeper)

100

1000

Radicans

1 year Seedlings

1 year Trans.

BUDDLEIA (Butterfly Bush)

Lining Out

12 to 18 inch 1 year.

$\begin{array}{ll}2.00 & 12.00 \\ 3.00 & 25.00 \\ & \\ 4.00 & 35.00 \\ 6.00 & 45.00 \\ & \\ 3.00 & 25.00 \\ 4.00 & 35.00 \\ 3.50 & 25.00 \\ 4.50 & 35.00 \\ 5.50 & 45.00 \\ & \\ 3.50 & 25.00 \\ & \\ 5.25 & 47.50 \\ 2.50 & 20.00 \\ 3.50 & 25.00\end{array}$

CHIONANTHUS VIRGINICA (White Fringe)

6 to 12 inch seedlings 2 year.

12 to 18 inch seedlings 2 year.

18 to 24 inch seediings 2 year.

22.50

CLETHRA ALNIFOLIA (Summer Sweet)

8 to 15 inch 2 year.

6.00

55.00

CELASTRUS SCANDENS (Bittersweet)

1 year seedlings No. 1.

$3.50 \quad 30.00$

1 year seedíngs No. 2 .

\section{CLEMATIS}

Paniculata

2 year seedlings.

3.00

25.00

4.00

35.00

CORNUS (Dogwood)

Alnifolia

12 to 18 inch.

Alba Sibarica (Coral Dogwood)

12 to 18 inch 1 year.

Amomum (Silky Dogwood)

6 to 12 inch 1 year..

Floridus (White Flowering)

6 to 12 inch seedlings, Nursery grown....................

12 to 18 inch seedilings, Nursery grown

18 to 24 inch seedlings, Nursery grown.

Lutea (Yellow Twigged Dogwood)

6 to 12 inch

12 to 18 inch

18 to 24 inch

Paniculata (Grey Dogwood)

6 to 10 inch 1 year.

10 to 15 inch 1 year.

Sanguinea (English Dogwood)

6 to 12 inch cuttings

12 to 18 inch cuttings.

18 to 24 inch cuttings 


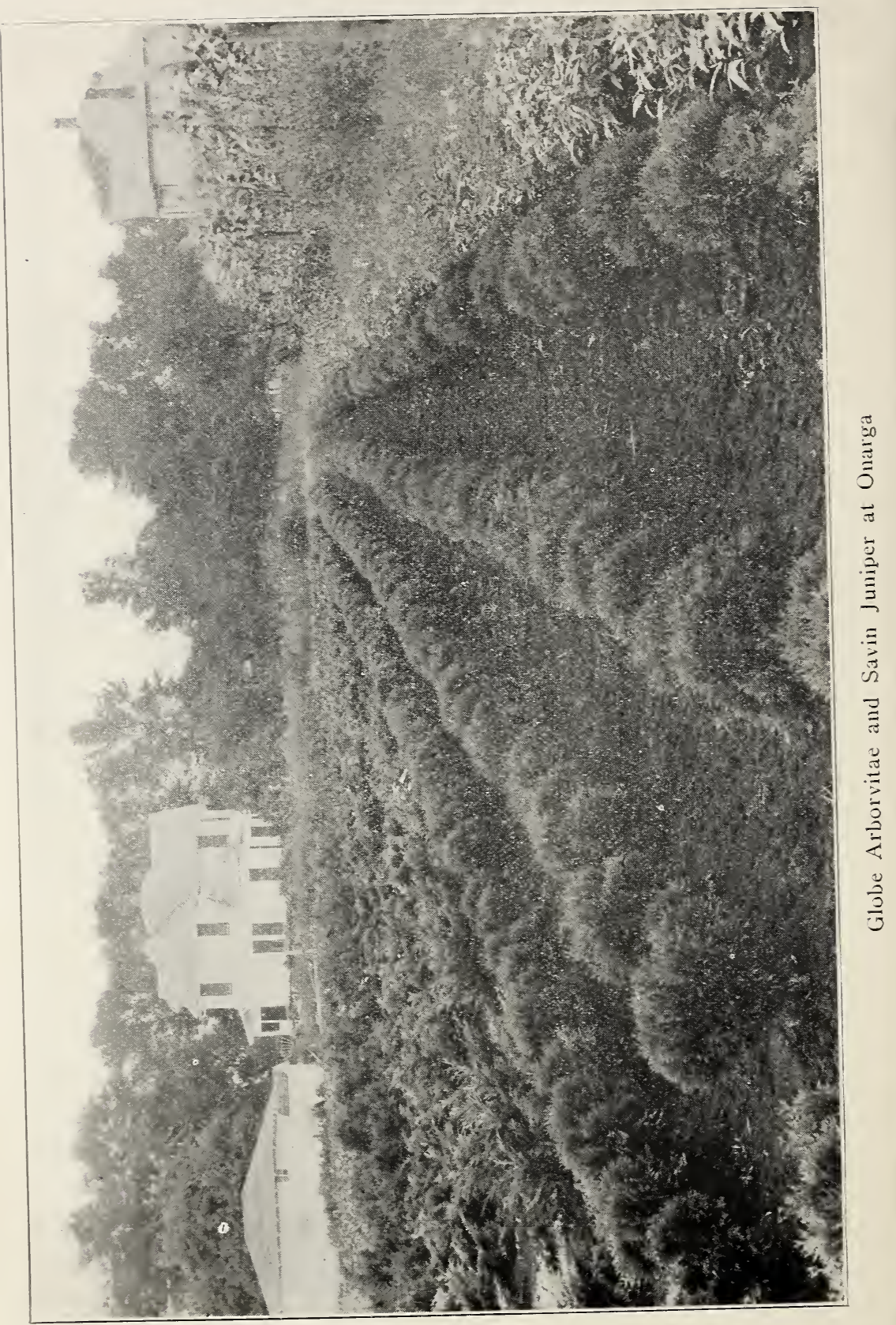




\section{LINING OUT STOCK \\ SHRUBS, VINES AND CREEPERS (Continued)}

CORNUUS (Continued)

Stolonifera (Red Osier Dogwood)

6 to $1:$ inch seedling 3 .

12 to 13 inch seedlings

$1.50 \quad 12.00$

18 to 24 inch seedlings.

COTONEASTER

Acutifolia

1 year seedlings

$6.00 \quad 50.00$

CYDONDA JAPONICA (Flowering Quince)

8 to $1:$ inch seedlings.

\section{DEUTZIA}

\section{Candidissima}

6 to 12 inch 1 year cutting

12 to 18 inch 1 year cuttings.

$2.50 \quad 20.00$

\section{Cranata}

18 to 24 inch 1 year cuttings

$5.00 \quad 40.00$

6 to 12 inch 1 year cuttings

12 to 18 inch 1 year cuttings.

18 to 24 inch 1 year cuttings

Fortunea

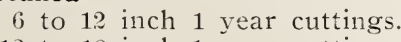

6 to 12 inch 1 year cuttings

12 to 18 inch 1 year cuttings.

18 to 24 inch 1 year cuttings.

\section{Gracilis}

2 year trans.

1 year rooted cuttings

\section{Lemoine}

$2.50 \quad 20.00$

$3.00 \quad 25.00$

$3.50 \quad 30.00$

$2.50 \quad 20.00$

$3.00 \quad 25.00$

$3.50 \quad 30.00$

$2.50 \quad 20.00$

$3.00 \quad 25.00$

$3.50 \quad 30.00$

$5.00 \quad 45.00$

$4.50 \quad 30.00$

10 to 15 inch 2 year.

$4.00 \quad 35.60$

15 to 24 inch 2 year

$5.00 \quad 45.00$

Pride of Rochaster

$1:$ to 18 inch

$3.00 \quad 25.00$

18 to 24 inch

$3.50 \quad 30.00$

\section{DUTCHMAN'S PIPE}

\section{Large Leaí}

2 year No. 1 Seedlings.

ELEAGNUS ANGUSTIFOLIA (Russian Olive)

8 to $1:$ inch 1 year

12 to 18 inch 1 year

$3.25 \quad 27.50$

18 to 24 inch 1 year

$3.75 \quad 32.50$

$5.50 \quad 50.00$

EUONYMUS

Alatus (Winged Euonymus)

$$
6 \text { to } 12 \text { inch } 2 \text { year. }
$$

\section{Amsricana}

12 to 18 inch

18 to $2+$ inch

\section{Radicans}

2 year cuttings

\section{Vegetus}

1 year

$\begin{array}{rr}8.00 & 75.00 \\ 2.00 & 12.00 \\ 2.50 & 20.00 \\ 15.00 & 110.00 \\ 4.00 & 35.00 \\ & \\ 5.50 & 50.00\end{array}$

FORSYTHIA

CHORDA GRANDIFLORA (Pearl Bush)

\section{Fortunea and Intermedia}

6 to 12 inch

12 to 18 inch

$3.00 \quad 25.00$

18 to 24 inch

$3.50 \quad 30.00$ 


\section{LINING OUT STOCK SHRUBS, VINES AND CREEPERS (Continued)}

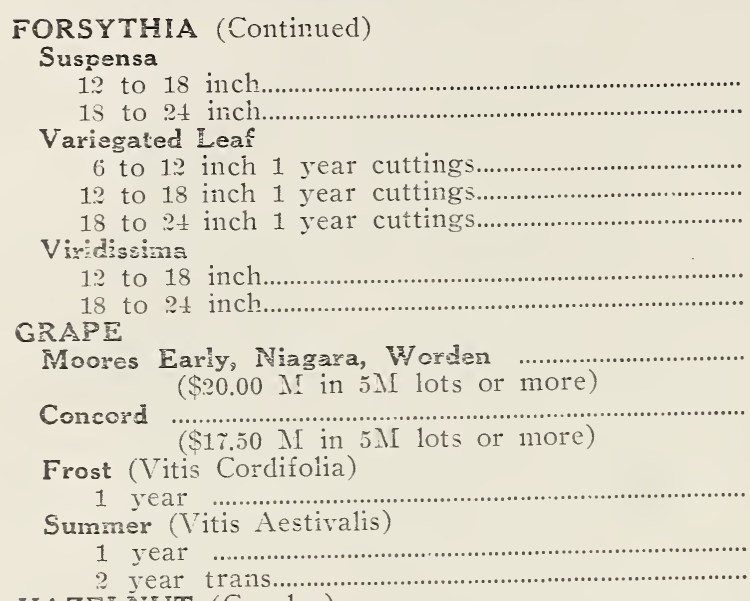

100

1000

3.50

3.00

3.50

25.00

$3.00 \quad 25.00$

$3.50 \quad 30.00$

$3.00 \quad 25.00$

$2.50 \quad 20.00$

25.00

4.00

25.00

$5.00 \quad 35.00$

HAZELNUT (Corylus)

Americen

6 to 9 inch 1 year.

10 to 15 inch 2 year..

18 to 24 inch Collected.

HOIVEYSUCKLE (Lonicera)

Bella Albida

6 to 12 inch.

12 to 18 inch

18 to 24 inch.

Fragrantissima

12 to 18 inch

18 to 24 inch

Grandiflora Pink

6 to 12 inch

12 to 18 inch

18 to 24 inch

Filals Japan Climbing .........................................................

Miorrowi asd Morrowii Prosirata

6 to 12 inch

12 to 18 inch

18 to 24 inch

4.50

10.010

6.00

55.00

5.00

45.00

2.50

20.00

3.00

25.00

4.00

35.00

$3.00 \quad 27.50$

$4.00 \quad 35.00$

$2.50 \quad 20.00$

$3.00 \quad 25.00$

$4.00 \quad 35.00$

$3.00 \quad 20.00$

$2.50 \quad 20.00$

$3.00 \quad 25.00$

$4.00 \quad 35.00$

$3.00 \quad 25.00$

4.00

4.50

2.50

20.00

3.00

4.00

2.50

3.00

25.00

35.00

12 to 18 inch

Taxtarian White 6 to 12 inch.

12 to 18 inch.

18 to 24 inch. 


\section{LINING OUT STOCK}

\section{HYDRANGEA}

\section{SHRUBS, VINES AND CREEPERS (Continued)}

\section{Arborescens Grandiflora}

2 year

Paniculata Grandifiora

$\begin{array}{rr}100 & 1000 \\ 6.50 & 60.00 \\ 6.00 & 50.00 \\ & \\ 3.00 & \\ 4.00 & \\ & \\ 3.00 & \\ 4.00 & \\ & \\ 8.50 & 80.00 \\ & \\ 25.00 & 200.00 \\ & \\ 3.50 & 25.00 \\ 4.50 & 40.00 \\ 5.50 & 45.00\end{array}$

\section{HYPERICUM \\ Densifolium}

6 to 15 inch layers

6 to 12 inch

12 to 18 inch.

\section{Prolificum}

6 to 12 inch.

12 to 18 inch.

KERRIA JAPONICA

15 to 24 inch 2 year.

KOLKWITZIA, New Shrub, Pink Flowers

12 to 18 inch trans

LINDERA BENZOIN (Spice Bush)

6 to 12 inch seedlings

12 to 18 inch seedlings.

LILAC (Syringa)

\section{Alphonse LaValle}

\section{Josikaea}

1 year from grafts

8 to 12 inch

Chas. X, Maria LeGraye, Ludwig Spaeth

6 to 12 inch

12 to 18 inch

Villosa

18 to 24 inch

No. 1 from grafts.

Vulgaris (Common Purple)

$t$ to 6 inch

$$
\text { ( } \$ 12.50 \text { per } \mathrm{M} \text { in } 5 \mathrm{M} \text { lots or more) }
$$

6 to 10 inch.

$$
10 \text { to } 15 \text { inch... }
$$

LYCIUM CHINENSE (Chinese Matrimony Vine)

MAHON⿴囗十 (Holly Grape)

$\begin{array}{rr}6.00 & 55.00 \\ 15.00 & 120.00 \\ 17.50 & 150.00 \\ 20.00 & 175.00 \\ 6.00 & 50.00 \\ 2.00 & 15.00 \\ 3.00 & 22.50 \\ 4.00 & 32.50 \\ & \\ 3.50 & 30.00 \\ & \\ 5.00 & 35.00\end{array}$

MALUS (Crab)

folra (Oregon Holly Grape)

Coronarius (Wild Sweet Crab)

10 to 15 inch 1 year....

PHIL:DELPHUS (Mock Orange)
Aurea

No. 1

Avalanche

2 year No. 1

Coronarius

6 to 12 inch

12 to 18 inch

18 to 24 inch

Falconeri

6 to 12 inch

12 to 18 inch

18 to 24 inch. 


\section{LINING OUT STOCK SHRUBS, VINES AND CREEPERS (Continued)}

PHILADELPHUS (Mozk Orange) (Continued) 100

1000

Gordonianus

6 to $1: 2$ inch

3.00

25.00

12 to 18 inch.

3.50

30.00

18 to $2 \frac{1}{4}$ inch.

4.50

40.00

Grand:flora

12 to 18 inch

$3.00 \quad 25.00$

18 to 24 inch

4.50

35.00

Lemoine

5.00

$3 \tilde{.00}$

Nont Blanc and Nivalis

6 to 12 inch 1 year cuttings.

$3.00 \quad 25.00$

12 to 18 inch 1 year cuttings

3.50

30.60

18 to 24 inch 1 year cuttings

$4.50 \quad 10.00$

Virginal

8 to 12 inch.

12 to 18 inch : year trans

$8.00 \quad 75.00$

$12.00 \quad 100.00$

Zeyheri

6 to 12 inch 1 year cuttings

$3.50 \quad 30.00$

$4.00 \quad 35.00$

12 to 18 inch 1 year cuttings

$5.00 \quad 45.00$

18 to 24 inch 1 year cuttings

$5.00 \quad 45.00$

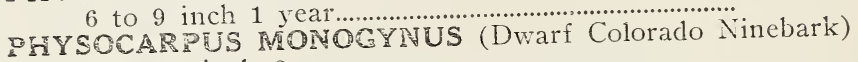

15 to 24 inch 2 year.

$4.50 \quad 10.00$

Opulifoliezs (Common Ninebark)

18 to 24 inch 1 year.

$3.00 \quad 25.00$

Luteus (Golden Leaf Ninebark)

15 to 24 inch 1 year.

$2.50 \quad 20.00$

POTENTILIA (Cinquefoil)

Fruticosa (Shrubby Cinquefoil)

8 to 12 incir.

PRIVET (Ligustrum)

Amour River North

10 to 15 inch

$$
\text { ( } \$ 15.00 \mathrm{M} \text { in } 10 \mathrm{M} \text { lots) }
$$

\section{Amour River South}

6 to 12 inch 1 year seedlings.

12 to 18 inch 1 year seedlings

18 to 24 inch 1 year seedlings

California

6 to 12 inch

( $\$ 8.00$ in $10 \mathrm{M}$ lots)

\section{Ibota Privet}

6 to 12 inch

12 to 18 inch

18 to 24 inch.

Regel's True Type

1 year rooted cuttings

Vulgare (European)

6 to 12 inch 1 year.

12 to 18 inch 1 year 2 branch 


\section{LINING OUT STOCK \\ SHRUBS, VINES AND CREEPERS (Continued)}

PRUNUS (Continued)

Tomaniosa (Nanking Cherry)

100

8 to 12 inch.

12 to 18 inch

Virginiana (Common Chokeberry)

8 to 12 inch 1 year.

15 to 24 inch 2 year.

PTELEA TRIFOLIATA (Hoptree)

8 to 12 inch 1 year

12 to 15 inch 1 year..

\section{PUERARIA}

Thunbergiana (Kudza Bean)

1 year

RHAMNUS (Buckthorn)

Cathartica (Common)

6 to 9 inch 1 year

9 to 12 inch 1 year.

Frangula (Glossy Buckthorn)

6 to 10 inch 1 year.

10 to 15 inch 1 year.

\section{RHODOTYPHUS}

Kerroides (White Kerria)

4 to 6 inch.

6 to 10 inch

10 to 15 inch

\section{RHUS (Sumach)}

\section{Aromatica \\ 2 year trans.}

\section{Copalina}

12 to 18 inch

18 to 24 inch

Glabra

2 to 3 feet.

12 to 18 inch

18 to 24 inch.

\section{Typhina}

2 to 3 feet.

18 to 24 inch

2 to 3 feet...

$3.50 \quad 30.00$

Typhina Laciniata

12 to 18 inch.

\section{RIBES}

Alpinum (Mountain Currant)

8 to 15 inch 2 year.

Americanum (American Black Currant)

$\begin{array}{ll}5.00 & 45.00 \\ 3.00 & 25.00 \\ 6.00 & 55.00 \\ 6.00 & 55.00\end{array}$

18 to 24 inch

Aurem (Slender Golden Currant)

15 to 18 inch 1 year.

Odoratum (Golden Currant)

15 to 24 inch 1 year. 


\section{LINING OUT STOCK \\ SHRUBS, VINES AND CREEPERS (Continued)}

ROSA ACACIA (Moss Locust)

100

Ruoted Layers

ROSA BLANDA

4 to 6 inch 1 year

3.00

3.00

15.00

8 to 12 inch

CAROLINA

6 to 8 inch 1 year.

ROSA HUGONIS

A HUMILIS

8 to 15 inch 1 year

3.00

3 to 5 inch 1 year...

ROSA MULTIFLORA

10 to 15 inch 1 year

15 to 24 inch 1 year

ROSA RUBIGINOSA

10 to 15 inch.

ROSA RUGOSA

No. 1 seedlings

ROSA SETIGERA

1 year No. 1.

ROSA WICHURIANA

1 vear No. 1

RUBUS ODORATUS (Flowering Raspberry)

12 to 18 inch 1 year.

SAMBUCUS (Elder)

Acutifolia (Cut Leaf Elder)

12 to 18 inch 1 year.

18 to 24 inch 1 year

Aurea (Golden Elder)

12 to 18 inch

Pubens (Red Berried)

8 to 12 inch

\section{SPIREA}

Anthony Waterer (Red)

1 year rooted cuttings

Arguta (White)

1 year rooted cuttings

2 year trans. Extra strong

Billardi (Pink)

12 to 18 inch

Caliosa Alba (White)

2 year trans.

Callosa Rosea (Pink)

12 to 18 inch

Douglassi (Deep Pink)

6 to 12 inch 1 year

12 to 18 inch 1 year

18 to 24 inch 1 year
3.00

1000

25.00

25.00

25.00

25.00

25.00

$2.25 \quad 20.00$

$3.00 \quad 25.00$

$4.00 \quad 32.50$

$3.50 \quad 30.00$

$3.50 \quad 30.00$

$3.00 \quad 25.00$

$5.00 \quad 45.00$

$2.50 \quad 20.60$

$3.00 \quad 2 \gamma .50$

$5.00 \quad 40.00$

$2.50 \quad 20.00$

$4.50 \quad 35.00$

$4 . \check{0} 0 \quad 35.00$

$6.00 \quad 50.00$

$4.00 \quad 32.50$

$5.50 \quad 50.00$

$3.50 \quad 30.00$

$3.50 \quad 30.00$

$4.00 \quad 35.00$

$4.50 \quad 40.00$ 


\section{LINING OUT STOCK \\ SHRUBS, VINES AND CREEPERS (Continued)}

SPIREA (Continued)

Froebelli (Pink)

1 year

2 year trans

Latifolia (Bethlemensis Pink)

12. to 15 inch 1 vear

Opulifolia

12 to 12 inch

Gpulifolia Aurea

6 to 12 inch.

12 to 19 inch

18 to 24 inch

Opulifolia Aurea Nana (Dwari)

$3.50 \quad 30.00$

18 to 24 inch

Prunifolia (Double Bridal IVreath)

Lining Out

Reevesiana (Double White)

$6.50 \quad 60.00$

6 to 12 inch.

Thurbergii

1 year rooted cuttings

Tomentosa

Var Houteii (Ithite)

10 to 15 inch

(\$20.00 per M in 5M lots)

18 to 24 inch

SYMPHORICARPUS (Snowberry)

Racemosus (Thite)

Vulgaris (Red)

12 to 15 inch.

1 s to $\rightarrow$ inch.

\section{TAMARIX}

Americana, Amurensis, Gallica

2 to 3 feet 1 year.

Africaña

\section{Pentandra}

2 to 3 feet 1 year.

2 to 3 feet 1 year.

\section{VIBURNUM}

\section{Americana}

12 to 18 inch

18 to 24 inch

\section{Dentatum}




\section{LINING OUT STOCK}

\section{SHRUBS, VINES AND CREEPERS (Continued)}

\section{VIBURNUM (Continued)}

100

1000

Lantana

9 to 15 inch 2 year

6.50

60.00

Lentago

18 to 24 inch 2 year......

8.00

65.00

Molle

6 to 10 inch 2 year.

45.00

Opulus (Highbush Cranberry)

$s$ to 12 inch.

12 to 18 inch.

$4.50 \quad 40.00$

$5.50 \quad 50.00$

$6.50 \quad 60.00$

Opulus Sierilis (Snowball)

Lining Out

8.00

75.00

Plicatum

No. 1

\section{VITEX}

Agnus Castus

6 to 12 inch seerling

12 to 18 inch seedlings

18 to $2 \pm$ inch seedlings.

\section{Incissa}

6 to 12 inch seedlings

12 to 18 inch seedlings

18 to 24 inch seedlings

$3.50 \quad 30.00$

\section{WEIGELA (Diervilla)}

\section{Candidz}

12 to 18 inch 1 year

Eva Rachke

2 year

2 year Trans

Lutea (Yellow)

6 to 12 inch 1 year.

12 to 18 inch 1 year.

Amabilis, Des Boise, Gustav Mallet, Hendersona,

Madam Lemoins, Rosea

1 year

2 year trans

\section{Variegata}

\section{WISTERIA}

\section{Chinese Blue and White}

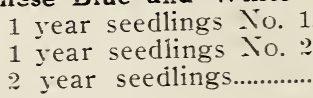

